\title{
1. PRELIMINARY REPORT ON LATE NEOGENE RED SEA FORAMINIFERA, DEEP SEA DRILLING PROJECT, LEG 23B
}

\author{
Robert L. Fleisher,' Department of Geological Sciences, University of Southern California, Los Angeles, California
}

\section{INTRODUCTION}

Six sites in the southern Red Sea were cored during DSDP Leg 23B, all of which were located near the center of the basin. At four of these - Sites 225, 227, 228, and 229 coring operations penetrated relatively thick Late Neogene sedimentary sequences. The planktonic and benthic foraminiferal faunas from cores recovered at these four sites provide the basis for the discussion presented in this paper. At Sites 226 and 230, sediment recovery was minimal because of operational difficulties. These Sites are described in the appropriate site reports (Chapters 16 and 20 , this volume), and no further consideration of them will be undertaken here. Location and recovery data for the four relevant sites are given in Table 1 and Figure 1.

Sites 225 and 227 were drilled at locations only a few kilometers apart, within but near the seaward edge of the eastern marginal zone and close to the Atlantis II and Chain deeps. Drilling operations penetrated sediments of Late Miocene to Quaternary age and were terminated in upper Miocene evaporites; the upper surface of these deposits is identified with a distinct seismic reflector the nature of which has been recognized by some authors (Tramontini and Davies, \footnotetext{
Texas.
}

1969), but thought by others (Knott et al., 1966; Ross, et al., 1969) to represent a Late Miocene or Early Pliocene unconformity. Post evaporite sediments are composed largely of calcareous nannofossils and, particularly at Site 227 , detrital clay and carbonate particles. Mica and sand-sized detrital grains are essentially absent, but pyrite is relatively common in many upper Miocene and Pliocene samples. For the most part, foraminifera are relatively common, constituting up to $10 \%$ of the sediment. Planktonic species predominate in upper Pliocene and Quaternary deposits, but the abundance of these forms is considerably reduced in the lower Pliocene section. Planktonic tests are absent from sediments immediately above the evaporites, as well as from interevaporite beds (a single exception, Sample 227-36, CC, contains rare specimens). Benthic foraminiferal tests are a minor element in terms of absolute abundance, although they are concentrated in the washed residues of lower Pliocene and upper Miocene samples by the scarcity of planktonic species.

At Site 228, located farther to the south and along the edge of the western marginal zone, a similar but somewhat thicker postevaporite sequence was penetrated. Most samples recovered at this site contain significant quantities of sand-sized detritus (mica and quartz sand), indicating the presence of a river drainage system which was probably operative in Sudan to the west. The general nature of the

TABLE 1

Location, Water Depth, and Recovery Data for Red Sea Sites

$225,227,228$, and 229

\begin{tabular}{lccccc}
\hline & 225 & 227 & 228 & 229 & $229 \mathrm{~A}$ \\
\hline Latitude (N) & $21^{\circ} 18.58^{\prime}$ & $21^{\circ} 19.86^{\prime}$ & $19^{\circ} 05.16^{\prime}$ & $14^{\circ} 46.09^{\prime}$ & $14^{\circ} 46.09^{\prime}$ \\
Longitude (E) & $38^{\circ} 15.11^{\prime}$ & $38^{\circ} 07.97^{\prime}$ & $39^{\circ} 00.20^{\prime}$ & $42^{\circ} 11.47^{\prime}$ & $42^{\circ} 11.47^{\prime}$ \\
Water Depth (m) & 1228 & 1795 & 1038 & 852 & 852 \\
Sediment Cores $^{\mathrm{a}, \mathrm{b}}$ & 21 & 25 & 32 & 5 & 18 \\
Total Cores $^{\mathrm{b}, \mathrm{c}}$ & 27 & 41 & 37 & 5 & 18 \\
\% Recovery & 59 & 35 & 58 & 75 & 73 \\
Age $^{\mathrm{d}}$ & Late & Late & Early & Late & Late \\
& Miocene & Miocene & Pliocene & Pleistocene & Pleistocene \\
Penetration (m) $^{\mathrm{c}}$ & 230 & 344 & 315 & 108 & 212 \\
\hline
\end{tabular}

\footnotetext{
a Includes only cores recovered from above the evaporites.

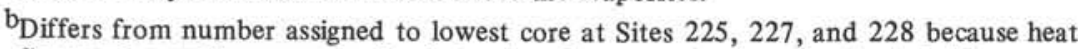
flow probes, with no penetration but assigned core numbers, are not included here.

${ }^{c}$ Includes all cores recovered at each site.

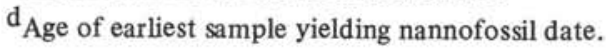




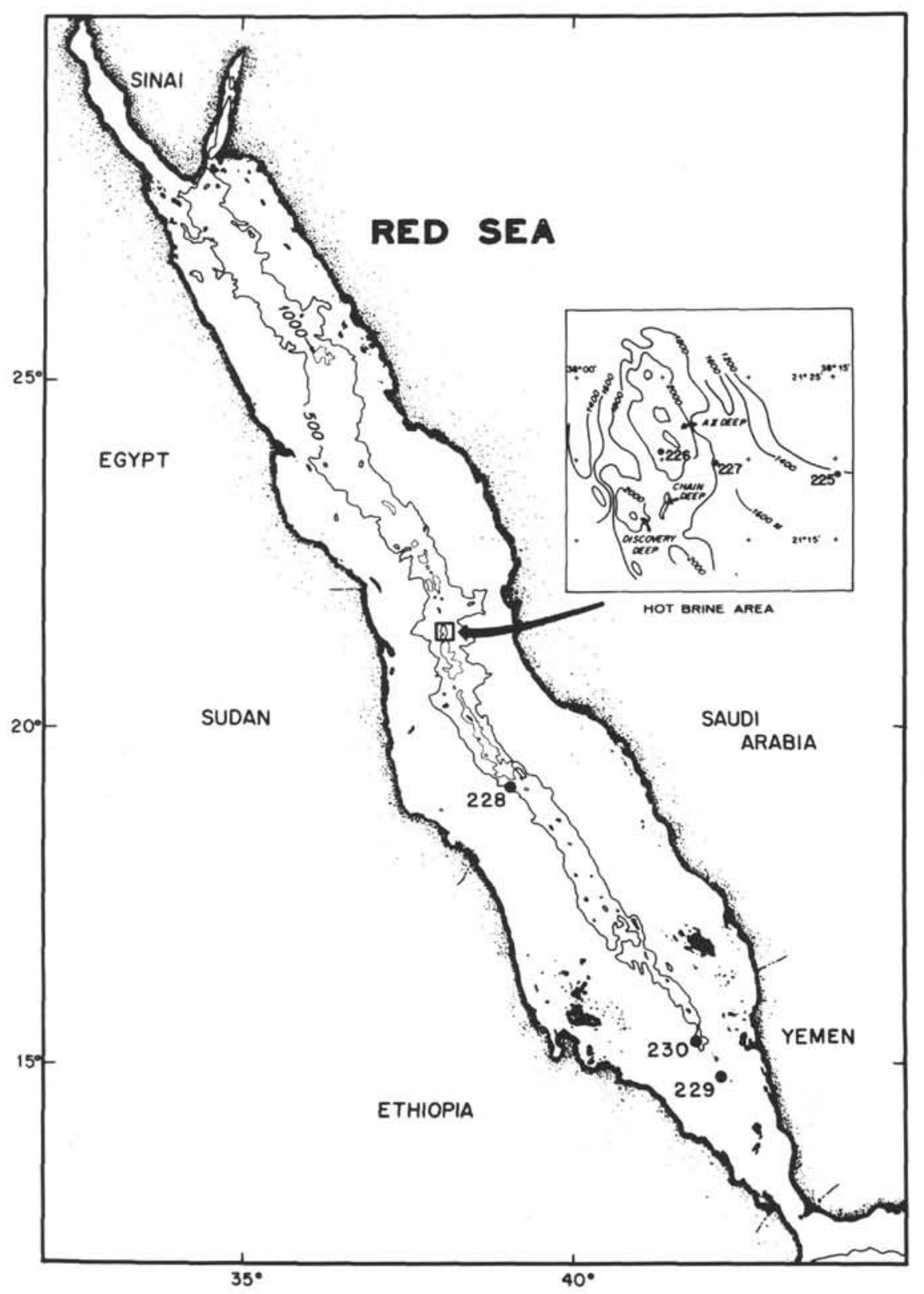

Figure 1. Location of drilling sites in the Red Sea. After Laughton, 1970, and Ross et al., 1973. Contours in fathoms on map, in meters on inset.

foraminiferal faunas, however, is similar to that observed farther north. The three sites described above have been collectively termed the "northern sites" in this paper.

Two holes achieving a total penetration of 212 meters were cored at Site 229, the southernmost station occupied in the Red Sea. The location of this site appears to lie within the boundaries of the axial trough (although it cannot be recognized here from sea-floor physiography) rather than the marginal zone, an interpretation (cf. Chapter 19, this volume) which implies the presence of approximately 500 meters of sediment above the igneous basement. High levels of gas in the sediment forced abandonment of the site, precluding determination of the nature and age of the basement. There was 148 meters of sediment recovered, primarily calcareous ooze, and most samples contained common planktonic and benthic foraminifera. Although penetration was comparable to that obtained at the other successful Red Sea sites, nannofossil data indicate that the lowest recovered samples are no older than Late Pleistocene. In view of the predominantly biogenous character of the sediments, it is clear that the high rate of accumulation (cf. Chapter 19, this volume) results in part from the deposition of large quantities of material derived, probably by slumping, from adjacent topographic highs.

The limitations and preliminary nature of both the data and the interpretations presented in this report must be emphasized. Low diversity among both planktonic and 
benthic foraminiferal populations has been a consistent characteristic of Red Sea faunas since the end of evaporite deposition in the Late Miocene. Recent studies (Berggren and Boersma, 1969; Meyer, 1973) have demonstrated the necessity of detailed species counts in interpreting short-term climatic events in the Red Sea record, but at present no such counts have been made on Leg 23B samples. It appears, in addition, that the duration of some of these fluctuations may be shorter than the time represented by the sampling interval employed here. As a result of the qualitative nature of the benthic and planktonic faunal investigations presented in this report, the emphasis has been placed on elucidation of the broad trends in Late Neogene paleoclimatology.

In view of these limitations, the present study must be considered preliminary in nature. A more detailed, quantitatively oriented investigation, with a substantially reduced sampling interval $(50 \mathrm{~cm})$, is currently in progress. The results of this study will provide the basis for a much more complete reconstruction of Late Neogene Red Sea paleoclimatology.

\section{PHYSIOGRAPHIC AND OCEANOGRAPHIC SETTING}

The character of the Red Sea benthic and planktonic foraminiferal faunas results almost entirely from the physiographic and oceanographic nature of the basin and its waters, the first of which is unusual and the second probably unique among marine basins of significant size. It is appropriate, therefore, to describe these features before discussing the fossil assemblages.

\section{Physiography}

The Red Sea is a narrow, elongated, linear basin, trending northwest-southeast and extending from the Sinai Peninsula in the north to the Straits of Bab-El-Mandeb and the Gulf of Aden in the south. Two northern extensions, the shallow Gulf of Suez and the much deeper Gulf of Aqaba, were not sampled and will not be considered here.

The physiographic subdivisions employed in this report are somewhat modified from those proposed by Knott et al. (1966). Coastal shelves, of ten with coral reefs, border both shorelines, but become narrow north of $17^{\circ} \mathrm{N}$ along the African coast and $20^{\circ} \mathrm{N}$ on the Arabian. The main trough, between the coastal shelves, has generally been recognized as a rift basin (e.g., Burek, 1969; Girdler, 1969; Lowell and Genik, 1972) and may be subdivided into three basinal regions: eastern and western marginal zones, and a narrow and deeper axial trough between them. The former are characterized by relatively thick undeformed to mildly disturbed sedimentary sequences, deposited upon a basement composed of basic igneous rock, probably with granitic material as well (Tramontini and Davies, 1969; Chapter 15 , this volume). Sediments are thin or absent over oceanic crust in the axial trough, and the evaporite sequence is apparently absent. South of $15^{\circ} \mathrm{N}$, where the sea floor is less than 500 meters deep, topographic expression of these subdivisions is lost, although the axial trough may be buried by younger sediments.

Water depths in the Red Sea are generally less than 1500 meters, but exceed 2000 meters in some of the deeper portions of the axial trough. A broad sill extends between $12^{\circ} 15^{\prime} \mathrm{N}$ (in the Gulf of Aden) and $14^{\circ} 30^{\prime} \mathrm{N}$, over which distance the bottom lies no deeper than 500 meters. The shallowest cross-section lies not at the narrowest point of the Straits of Bab-El-Mandeb (at $12^{\circ} 40^{\prime} \mathrm{N}$, near Perim Island), but near Hanish Island $\left(13^{\circ} 41^{\prime} \mathrm{N}\right)$. At this location, the maximum depth is only about 100 meters.

\section{Surficial Waters}

\section{Circulation Patterns}

Although the physical and chemical oceanography of the Red Sea are incompletely known and understood, several recent publications (Morcos, 1970; Patzert, 1972) indicated the nature of the general oceanographic patterns and the important role of the shallow sill. In addition to restricting the volume of inflow, the sill limits the entering flow to surface and near-surface waters and prohibits the free circulation of deep water between the Red Sea and Gulf of Aden. Thus, not only does it control the foraminiferal fauna indirectly (as a dominant factor influencing circulation and salinity), but directly, in that the only planktonic species entering the Red Sea are those that live within 100 meters of the sea surface. Similar depth control appears to have been a persistent factor in the development of benthic species assemblages as well.

Surface circulation in the southern Red Sea appears to be largely controlled by wind patterns (Patzert, 1972), although evidence for this model is based largely on ship drift positions rather than on direct current measurements. North of $19^{\circ} \mathrm{N}$, prevailing winds are from the north-northwest throughout the year, but farther south wind directions change twice annually. During the winter (October through May), weak north-northwest and stronger south-southeast winds converge at, or south of, $19^{\circ} \mathrm{N}$; the northernmost limit of the convergence is reached from October to December. In January, the south-southeast winds begin to weaken and the convergence is displaced southward. From June through September, winds are from the north-northwest throughout the entire length of the Red Sea. In October, the south-southwest wind system in the south is rapidly reestablished, and the winter pattern resumes.

The surficial (surface and intermediate) water circulation system behaves in response to these wind patterns. In winter, surface water flows from the Gulf of Aden into the Red Sea; the surface layer is approximately 40-70 meters in thickness (Patzert, 1972); and current velocities of $60-80 \mathrm{~cm} / \mathrm{sec}$ (Siedler, 1968) have been measured in the Straits of Bab-El-Mandeb. This layer is partially mixed with intermediate water at the sill and travels northward to approximately $26^{\circ} \mathrm{N}$ during most of the winter season, beyond the range of the south-southeast winds. At this latitude a convergence zone, in the form of a large cyclonic eddy system, develops between the inflow and the southward-flowing currents from the northern Red Sea. Intermediate water - cooler, denser, and more saline than the surface water from which it forms by evaporation flows in to the Gulf of Aden across the sill under the surface inflow. From October to May, therefore, water flow through the straits occurs in the form of a two-layer system. Because rainfall and river drainage into the Red Sea 
are negligible and the water lost by evaporation (Privett, 1959) constitutes only about $5 \%$ of the volume calculated for inflow (Patzert, 1972) from current measurements, it would appear that inflow and outflow, during most of the year, are nearly in balance.

During the remainder of the year, water flow above the sill is modified in response to the summer wind pattern, and a three-layered flow develops. A thin surface current of warm, high-salinity water flows from the Red Sea into the Gulf of Aden at velocities that appear to be approximately equivalent to those observed during the winter. Between 30 and 80 meters, cool, low-salinity, low-velocity $(10 \mathrm{~cm} / \mathrm{sec}$; Patzert, 1972) water enters the Red Sea and gradually mixes with the surface waters. Finally, the basal layer consists of highly saline Red Sea water flowing southward; thus, the currents immediately above the sill flow out of the Red Sea throughout the year.

\section{Temperature and Salinity}

Maximum surface temperatures in the southern Red Sea range from $26^{\circ} \mathrm{C}$ (January and February) to $32^{\circ} \mathrm{C}$ (July through September), with the highest values occurring south of $20^{\circ} \mathrm{N}$ and decreasing northward. The locations of the temperature maxima are closely related to regions of low wind velocity. In winter months, highest temperatures are recorded from locations between $17^{\circ} \mathrm{N}$ and $20^{\circ} \mathrm{N}$ near the convergence of north-northwest and south-southeast winds, and in June through September near $16^{\circ} \mathrm{N}$, where the velocity of the north-northwest winds is lowest. This relationship, a result of the cooling effect of wind-induced evaporation, accounts for the general northward temperature decline. A gradual decrease in temperature with depth is present in intermediate waters, but the position of the $22^{\circ} \mathrm{C}$ isotherm at approximately 200 meters depth over most of the Red Sea appears to be relatively constant throughout the year (Patzert, 1972).

Distribution of salinity values appears to be somewhat less closely tied to wind system patterns. During winter months, surface water entering through the straits (Morcos, 1970) mixes rapidly with more saline intermediate water, and values at the sill reach $36.5 \%$. A gradual increase in salinity occurs as the surface currents move northwestward; at $22^{\circ} \mathrm{N}$, values approach $39.0 \%$ (Patzert, 1972); and near the Gulf of Suez, salinities in excess of $41.0^{\circ} \%$ are attained. During the summer, somewhat similar patterns prevail, but the isohalines in the southern Red Sea are displaced somewhat southward because of the prevailing surface flow. Intermediate water salinity trends are similar during winter months, but the northward gradient is slightly steeper. From July through October, a lobe of less saline water extends several degrees northward from the sill, a reflection of the middle-layer inflow from the Gulf of Aden. At sill depth $(100 \mathrm{~m})$, salinities vary only slightly (39.0-40.4) \% everywhere north of $15^{\circ} \mathrm{N}$ (Patzert, 1972).

\section{Deep Water}

Circulation patterns in Red Sea deep water (greater than $200 \mathrm{~m}$ ) are essentially unknown. The deep water is formed primarily in the northern Red Sea (Morcos, 1970) from the sinking of cool, high-salinity surface water. A recently proposed model (Grasshoff, 1969) suggests that the deep water thus formed flows slowly southward along the basin axis and rises upon encountering the sill. Most then flows northward above the bottom flow, but a portion mixes with overlying intermediate waters and another part flows out over the sill. Temperature and salinity data from the region of the sill (Siedler, 1968; 1969) suggest that deep water outflow is relatively small compared to intermediate and surface-water volumes. While the data necessary to confirm this model are not currently available, it seems likely that interaction between the surficial and deep waters is minimal. If the volume of deep water is essentially constant under modern conditions, and outflow and mixing with intermediate waters are very low relative to the total deep-water volume, then the amount of deep water formed in the northern Red Sea annually must be similarly small. Based on the assumption that the two circulation systems are thus largely independent, Siedler (1969) has calculated a renewal time for surface waters of approximately 6 years, while the period of deep-water renewal would be much longer (cf. also Craig, 1969).

Below 200 meters, temperature and salinity values are unusually high and remarkably uniform (Siedler, 1968; 1969; Grasshoff, 1969). Temperatures range from $21.6^{\circ} \mathrm{C}$ to $21.8^{\circ} \mathrm{C}$ at depths as great as 1500 meters, values considerably higher than those noted at equivalent depths in other, more normal ocean basins. Salinity varies from $40.5 \%$ to slightly greater than $40.6 \%$, (the exceptionally high values attributable to the source of deep water). Temperature and salinity both increase very slightly with depth, but the dominant feature of this oceanographic regime is the uniformity which results from the presence of the sill to the south, eliminating intercommunication with the deep waters of the Gulf of Aden and the Indian Ocean.

\section{PLANKTONIC FORAMINIFERA}

In almost no other modern deep-water tropical or subtropical basin is the species composition of planktonic foraminiferal assemblages so completely controlled and limited by prevailing oceanographic conditions. Detailed studies of Late Quaternary faunas (Herman, 1965; Berggren and Boersma, 1969; Meyer, 1973) have demonstrated that only a small number of species can tolerate the salinities and temperatures prevalent in central Red Sea surface waters. One of the most readily apparent findings of this preliminary study is that similar, but usually more restricted, faunas have existed there since the end of the Miocene. At no time during this interval have open-ocean assemblages lived in the Red Sea; indeed, the modern faunas are among the most diverse associations to have inhabited the basin since the termination of evaporite deposition.

The limited species composition of the planktonic faunas precludes any direct correlation with open-ocean zonation systems based on evolutionary events. Of the relatively common species observed in Leg 23B samples, all but four evolved earlier than the time represented by the oldest recovered samples, and are still living. Of the four exceptions, two ("Globigerina" rubescens rubescens and " $G$." tenella) are known to have evolved during the Pliocene (Blow, 1969), but there is reason to believe that their earliest Red Sea occurrences were controlled by 
environmental factors rather than evolutionary development. The others ("Globigerina" rubescens decoraperta and Globigerinoides obliquus) disappeared locally near the Pliocene-Pleistocene boundary; these faunal events may approximately correlate with the extinction of these species in the open ocean.

Because of the low diversity of the foraminiferal faunas, biostratigraphic correlation with extrabasinal regions has been based in these reports solely upon the ranges of calcareous nannoplankton (cf. site reports and nannofossil range charts, this volume). Some question must remain as to whether the observed nannofossil events have the same time significance as in normal marine sequences, but there is no direct evidence of heterochroneity. In fact, the remarkably well developed and diverse nannofloras, in contrast to the highly restricted foraminiferal and radiolarian assemblages, suggests that these organisms were relatively unaffected by the unusual oceanographic conditions which apparently prevailed in the Red Sea during the Late Neogene.

\section{Planktonic Foraminiferal Biofacies}

The observed species associations have been divided, more or less successfully, into four assemblages, each with a relatively characteristic fauna. These presumably represent the foraminiferal biotas during the maintenance of a particular set of dominant environmental conditions. Faunal variations would thus reflect fluctuations in combinations of temperature, salinity, depth of the surficial water circulation system, or other ecological factors not recognized. Each group is named after one of the characteristic species, e.g., Globigerinoides ruber Assemblage.

In a general sense, the assemblages are of some value in correlating among the northern sites. As a result, it has proved possible and convenient to recognize four zones, each of which includes the interval dominated by the respective faunal assemblage. The distincition made here between, for example, the Globigerinoides quadrilobatus Assemblage and the G. quadrilobatus Zone is important to the discussions which follow. While most of the samples in the interval assigned to each zone contain faunas referred to the assemblage named for the same species, most of the zonal intervals contain isolated occurrences of other assemblages. As Site 228, for instance, the $G$. quadrilobatus Zone includes several horizons containing the $G$. ruber Assemblage; short-term fluctuations of this sort are not uncommon, particularly in lower Pliocene sequences, and the zone boundaries are sometimes difficult to delineate. In large part, however, this report will deal with the generalized sequence, which occurs in the same order at each northern site. It seems likely, in view of the systematic oceanographic variations in modern Red Sea waters, that the zone boundaries are probably slightly time transgressive over any significant latitudinal range. Much more detailed work, and closer sampling patterns, will be required to determine the order and probable significance of the short-term faunal changes.

The defining characteristics of each assemblage will be discussed here, in descending stratigraphic order, so as to provide a framework within which species occurrences can be considered.

1. Globigerinoides quadrilobatus Assemblage: This association is characterized by the presence of $G$. quadrilobatus, and although direct comparison is difficult on the basis of published accounts, the species composition appears to correspond in part to the faunas referred by Berggren and Boersma (1969) to their zones A and D and to Herman's (1965) "warm" intervals. The diversity is generally highest in samples containing this assemblage: Globigerinoides quadrilobatus, G. ruber, Globigerinita glutinata, and Turborotalita "quinqueloba" are usually common or abundant, and Orbulina universa, Globigerinella siphonifera, and "Globigerina" rubescens rubescens, while less common, are often present. Several other species are present in occasional samples, particularly at Site 229. The G. quadrilobatus Zone is nearly, but not quite, coincident with the Pleistocene (according to nannofossil data); its first appearance is Late Pliocene in age at Site 225 and Early Pleistocene at Site 228.

2. Globigerinoides ruber Assemblage: Distinctive reduced-diversity faunal associations in the Late Pliocene prior to the appearance of the G. quadrilobatus Assemblage are characterized by the presence, generally abundant, of $G$. ruber, often with relatively common $G$. obliquus, without co-occurring $G$. quadrilobatus. Usually accompanying these two species are "Globigerina" rubescens rubescens, " $G$." rubescens decoraperta, Globigerinita glutinata, and Turborotalita "quinqueloba." Most samples containing this fauna are of Late Pliocene age, but it occasionally appears in both lower Pliocene and Pleistocene sediments. The $G$. ruber Assemblage appears to correspond to the fauna of zone C of Berggren and Boersma (1969); the relation to Herman's (1965) zones is less clear.

3. Globigerinita glutinata Assemblage: The variations in composition of the planktonic faunas in the Red Sea prior to the consistent appearance of the $G$. ruber Assemblage are considerably more complicated than those of higher biofacies, and it is not clear, on the basis of the available data, precisely how these faunas should be subdivided. Two groupings have been tentatively recognized.

Most samples included in the G. glutinata Assemblage are characterized, as representative of this association, by common occurrences of G. glutinata and Turborotalita "quinqueloba" and the absence of Globigerinoides spp. Also included here, however, are a small number of populations dominated by one or more of several other species, notably Globigerina cf. praebulloides and Turborotalia sp. 1. It seems unlikely that these samples represent precisely the same set of environmental conditions as others in the assemblage to which they are assigned; the associations in question, however, seem to be most closely related to $G$. glutinata faunas, although they are generally located within the Turborotalita "quinqueloba" Zone as used here. As a rule, the G. glutinata Zone is more difficult to recognize, as a distinct sequence of samples, than either the Globigerinoides quadrilobatus or $G$. ruber zones. To a greater degree than with the two higher zones, samples containing this fauna alternate with those of other assemblages, primarily the G. ruber and T. "quinqueloba" assemblages. The same difficulty in drawing boundaries applies to a lesser degree to the $T$. "quinqueloba" Zone. 


\section{R. FLEISHER}

4. Turborotalita "quinqueloba" Assemblage: The lowest diversity planktonic populations in Red Sea sediments are generally representative of the $T$. "quinqueloba" Assemblage. In most samples, only the nominate taxon is present, although Globigerinita uvula and Streptochilus globigerum occasionally occur as well. The lowest recovered planktonic faunas usually belong to this grouping, but it may be found in isolated samples considerably higher (e.g., within the $G$. quadrilobatus Zone at Site 228), and commonly alternates with $G$. glutinata and $G$. ruber assemblage faunas in the Early Pliocene. It may be that this fauna represents a transported (and sorted) population, in view of the small size of the tests, but for the most part (except at some horizons in Holes 229 and 229A) the associated benthic foraminifera are considerably larger, and thus are probably in place.

The zones as recognized here are not equally represented at each of the Red Sea sites, but all except the Globigerinita glutinata Zone are represented by a thick section in at least one hole (Figure 2). Globigerinoides quadrilobatus
Assemblage faunas occupy the upper 125 meters of recovered section at Site 228 , and most of the interval penetrated at Site 229 (assuming that the assemblages as defined can be applied with any significance at this southern site). The $G$. ruber Zone is similarly represented by a relatively thick $(100 \mathrm{~m})$ sequence at Site 228 , as opposed to 25 meters at Site 225. At Site 227, the $G$. ruber Zone is absent, and the G. quadrilobatus Zone limited to no more than 25 meters of sediment, as the result of an unconformity. The remaining 140 meters of sediment with planktonic tests contain faunas assigned largely to the Turborotalita "quinqueloba" Zone.

Because of the nature of the criteria used to define these assemblages, it is not anticipated that the groupings as herein recognized will prove entirely satisfactory after more detailed study. The biofacies groups are characterized by the presence or absence of key species, and the composition of the remainder of the population has received less attention. This approach is not without merit, as demonstrated in the results obtained by similar studies

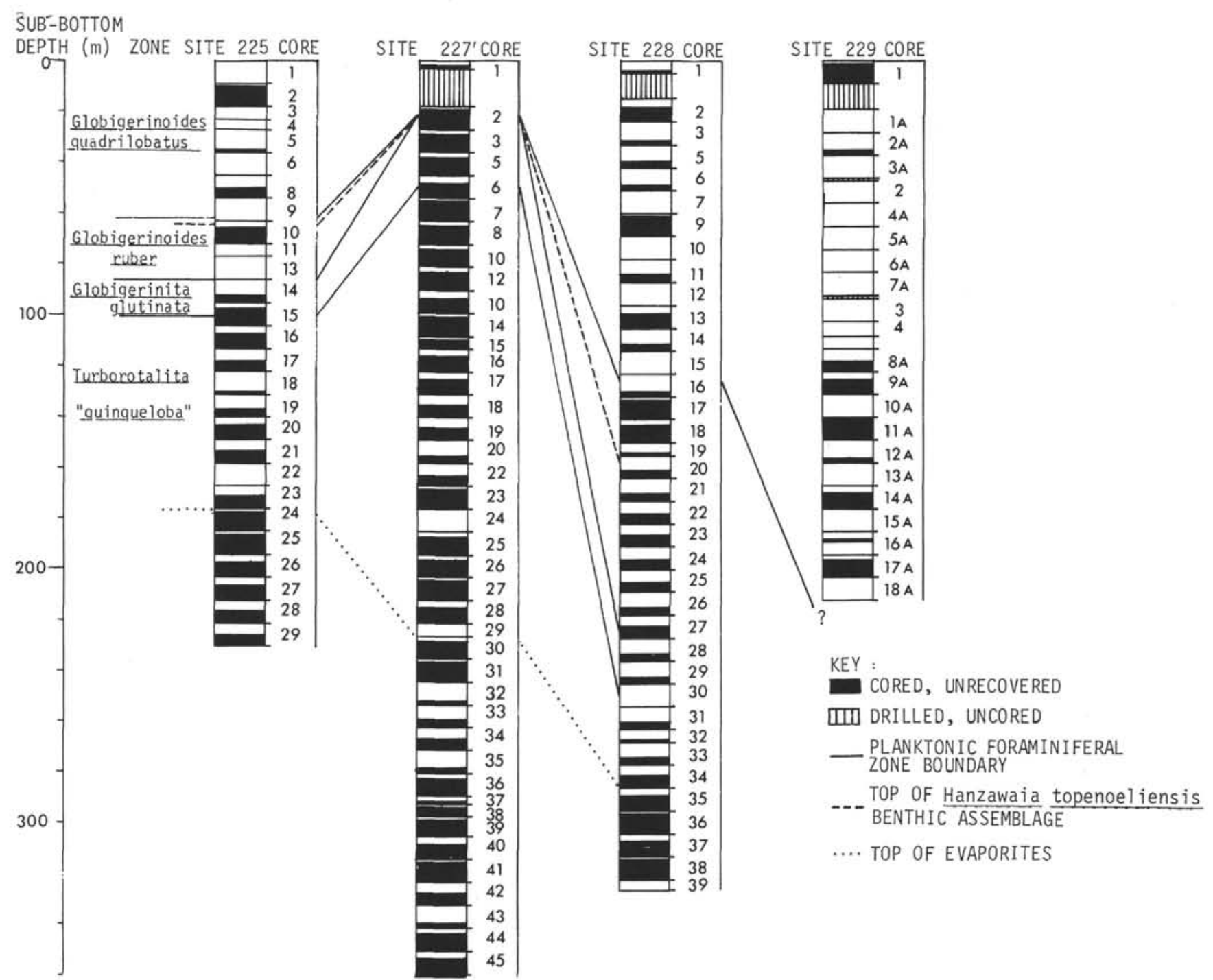

Figure 2. Correlation of Red Sea sites. 
(Berggren and Boersma, 1969; Berggren, 1969), but clearly much valuable information is overlooked. Quantitative variation in species composition of these assemblages is so complex, in spite of the limited number of species, that it appears likely that statistical analysis will be necessary to establish valid zonation systems and interpret paleoenvironmental trends.

\section{Distribution of Planktonic Species}

Planktonic foraminiferal species distribution in the Leg 23B cores varies not only with time, in response to modifications in surface water conditions, but with geographic position relative to the straits as well. It is important, therefore, to note that throughout most of the year temperature and salinity in the top 100 meters of water are very similar at the three northern sites. These locations are separated by less than $2.5^{\circ}$ of latitude, and differences in temperature and salinity among them at any given time are rarely greater than $1{ }^{\circ} \mathrm{C}$ and $0.5 \%$, respectively. In view of the generally high values of both parameters relative to normal sea-surface environments and the averaging effect on the data of examining samples several centimeters in vertical extent (thus effectively masking seasonal faunal variations), it seems likely that climate-induced differences in the fauna at the three sites will be minor. In fact, only one species (Globorotalia cultrata) was observed in significant numbers at Site 228 and not at Sites 225 and 227.

Site 229 is located much nearer to the sill. Surface water temperatures are similar to those prevailing at the northern sites, except at depths between 20 and 100 meters during the summer, when water at Site 229 is considerably cooler because of middle layer inflow. Salinities, by contrast, are usually $1.5-2.5 \%$ lower, depending upon water depth and season.

The following section describes the planktonic foraminiferal species observed in Leg 23B sediments, and their distribution in the cores recovered at Red Sea sites.

\section{Globigerina bulloides}

Tolderlund and Bé (1971) have questioned the identification of forms assigned to this taxon from tropical and subtropical waters, but specimens observed in Red Sea cores are typical of the species. A few occurrences of $G$. bulloides were observed with the Globigerinoides quadrilobatus Zone at Site 225, but it it otherwise absent at the northern sites. In sediments recovered at Site 229, this species is common to abundant in most samples, except where planktonic species are rare or where the populations are dominated by Turborotalita "quinqueloba." The abundance of $G$. bulloides tends to be somewhat higher, at the southern locality, in samples containing abundant Globigerinoides quadrilobatus and increased-diversity faunas.

\section{Globigerina calida}

This species was observed as very rare specimens in only two samples (Sites 225 and 229); both occurrences are within the upper levels of the Globigerinoides quadrilobatus Zone.

\section{Globigerina cf. praebulloides}

The morphotype included here differs from $G$. bulloides primarily in possessing a more restricted aperture and less distinct umbilicus, and from $G$. praebulloides in having a less circular aperture and $3 \frac{1}{2}$, rather than 4 , chambers in the final whorl. Although the faunal affinities of $G$. cf. praebulloides are not clear, it has recently been reported from modern cool-water populations (Bandy, 1972b, fig. 2, no. 4). It occurs only at the northern sites and in isolated samples, particularly from the Turborotalita "quinqueloba" Zone, where it is sometimes common. It is occasionally present in reduced numbers in horizons within the Globigerinoides ruber and Globigerinita glutinata zones.

\section{"Globigerina" rubescens rubescens}

A discussion of the generic assignment of this and the following two species is beyond the scope of this paper (cf. Fleisher, Chapter 39, this volume) but on the basis of surface wall texture these forms clearly seem to be unrelated to Globigerina s.s., and no satisfactory substitute name appears to be available.

At the northern sites, "G." rubescens rubescens is present, usually common, in most samples above the top of the Globigerinita glutinata Zone, but absent below, even in samples containing Globigerinoides ruber Assemblages. The initial appearance of the species is thus within the Late Pliocene in the Red Sea, somewhat above the reported level of its evolution in open-ocean sequences (Parker, 1967; Blow, 1969; Brönniman and Resig, 1971). The limitation of this form to the Globigerinoides quadrilobatus and $G$. ruber Zones indicates that the initial occurrence of " $G$." rubescens rubescens in the Red Sea is controlled by environmental, rather than evolutionary, events.

At Site 229, this species is consistently common in sediments as low as Core $12 \mathrm{~A}$, but relatively rare below. The reasons for this change in abundance are not clear.

\section{“Globigerina” tenella}

"G." tenella was probably not consistently separated from " $G$." rubescens rubescens in the faunal examinations; the recorded distribution is presumably less than desirably precise. At the northern sites, " $G$." tenella is entirely limited to the Globigerinoides quadrilobatus Zone, but first appears above the base and is relatively common only in the upper part. As in the preceding species, the local initial appearance occurs later than the recorded evolutionary development of the taxon and is probably controlled by environmental conditions. At Site 229, the distribution is essentially the same as that of " $G$." rubescens rubescens.

\section{“Globigerina" rubescens decoraperta}

This species is present, and relatively common, only at Sites 225 and 228 , where its range is essentially coincident with the Globigerinoides ruber Zone. Its extinction is slightly older (Late Pliocene Discoaster brouweri Zone) at the former than at the latter (Early Pleistocene Pseudoemiliania lacunosa Zone), a circumstance which may result from slight contemporanceous environmental differences between the two sites. The Early Pleistocene 
extinction approximates the species's disappearance in open-ocean sequences (Blow, 1969).

\section{Globigerinella siphonifera}

In the three northern sites, Globigerinella siphonifera is present only within the Globigerinoides quadrilobatus Zone and is relatively common only in the upper part of this interval. While abundances of this species are consistently much lower than those of $G$. quadrilobatus, it tends to be relatively common only in those samples in which $G$. quadrilobatus is particularly abundant; these two species apparently respond in a similar manner to fluctuations in surface water conditions. At Site 229, G. siphonifera is present throughout the recovered interval, but occurrences are somewhat sporadic below Core 13A.

\section{Globigerinita glutinata}

In principle, the author recognizes three subspecies of this taxon: $G$. glutinata glutinata (nonbullate, like the holotype), which has commonly been referred to $G$. juvenilis (Brönnimann and Resig, 1971; Jenkins and Orr, 1972); G. glutinata ambitacrena (bullate); and G. glutinata parkerae (with secondary apertures), a form referred by Brönnimann and Resig (1971) to G. glutinata flparkerae. These subspecies were not recorded separately during the preparation of this report, and no firm data relating to their relative abundances can be presented. There is some indication, however, that they may have differing environmental tolerances (O.L. Bandy, personal communication). The presence of all three forms in the higher levels of the northern holes, and the absence of all but the nominate subspecies in the $G$. glutinata Zone, tends to support this hypothesis.

G. glutinata is usually present, and frequently common, in samples from the Globigerinoides quadrilobatus, $G$. ruber, and Globigerinita glutinata zones, but occurs only sporadically within the Turborotalita "quinqueloba" Zone. At Site 227, it is often absent in samples within this last zone containing relatively small faunas but common Globigerinoides ruber.

\section{Globigerinita uvula}

This small species is found only very rarely in the Red Sea sediments. The few samples in which $G$. uvula was observed are predominantly within the Turborotalita "quinqueloba" Zone.

\section{Globigerinoides conglobatus}

This species is rarely common, and for the most part, is present only in the upper horizons of the G. quadrilobatus Zone. Below this, at the northern sites, $G$. conglobatus is rare and occurs only sporadically, except at Site 228, Sample $26 \mathrm{CC}$, where it is common in a $G$. ruber Zone sample with rare G. quadrilobatus. At Site 229, this form is present only as rare specimens in samples from Core $3 \mathrm{~A}$.

\section{Globigerinoides obliquus}

Only the nominate subspecies of $G$. obliquus is present in significant numbers in the Red Sea sediments, and $G$. obliquus extremus was not differentiated. The species is limited in range to $G$. ruber Assemblages; below the base of the $G$. quadrilobatus Zone, it is usually associated with, but somewhat less abundant than, G. ruber. At Site 227, it is present, and sometimes common, in several samples within the Globigerinita glutinata and Turborotalita "quinqueloba" Zones; in Samples 7,CC and 10,CC, G. obliquus is the dominant faunal element. The species is absent throughout the recovered section at Site 229.

It appears from the distribution patterns within the cores that the environmental tolerances of $G$. obliquus are quite similar or identical to those of $G$. ruber. Because the local extinction of $G$. obliquus near the PliocenePleistocene boundary is not associated with apparent changes in the abundance of $G$. ruber, it may approximately correspond to the extinction horizon recorded outside this basin.

\section{Globigerinoides quadrilobatus}

Three forms of this species-G. quadrilobatus quadrilobatus, G. quadrilobatus sacculifer, and G. quadrilobatus immaturus-were observed during the study of the samples, but were not distinguished during the faunal analysis. Recent data, however, suggest that the ratio between sacculifer and quadrilobatus forms may have environmental significance (Meyer, 1973).

At the northern sites, $G$. quadrilobatus is present, usually common to abundant, in samples of Pleistocene age, although its abundance decreases with depth. At Site 225, it occurs consistently in Cores 1 through 9, defining the $G$. quadrilobatus Zone, and is found sporadically (although it is generally absent) through Core 11. This species is common in Cores 1 and 2 at Site 227, but rare and sporadic below. At Site 228, it is present in most samples from the top 16 cores, with rare isolated occurrences in older horizons.

G. quadrilobatus is common or abundant in most samples at the southern site, but is absent in Cores 3 and $14 \mathrm{~A}$ through $15 \mathrm{~A}$.

\section{Globigerinoides ruber}

$G$. ruber is consistently present, and frequently the dominant species, in samples from the $G$. quadrilobatus and $G$. ruber zones. This interval encompasses Cores 1 through 13 at Site 225, the top two Cores at Site 227, and Cores 1 through 29 at Site 228 . It occurs as well in a number of samples in the Globigerinita glutinata and Turborotalita "quinqueloba" zones, where environmental conditions appear to have fluctuated considerably over short periods of time. In Holes 229 and 229A, this species is common in virtually all samples except those few containing $T$. "quinqueloba" Assemblage faunas.

\section{Globorotalia (Globorotalia) cultrata}

The subgeneric classification used here for species of Globorotalia is essentially that proposed by Bandy (1972a), except that Menardella is not recognized. No attempt has been made to separate $G$. $(G$.) cultrata cultrata and $G$. $(G$.) cultrata menardii.

At the northern sites, $G$. (G.) cultrata occurs very rarely at Sites 225 and 227 and somewhat more frequently (but rare nonetheless) at Site 228; in all cases it is found only within the Globigerinoides quadrilobatus Zone. At Site 
229 , this species is fairly common as low as Core $10 \mathrm{~A}$, but is somewhat less frequent below. The distribution of $G$. (G.) cultrata appears to be controlled more by geographic location than by zonal (i.e., temporal) association, which suggests that conditions north of $20^{\circ} \mathrm{N}$ in the Red Sea are too severe for it to thrive. It is absent in most samples containing $G$. (G.) limbata.

\section{Globorotalia (Globorotalia) limbata}

This species occurs in a few samples at the northern sites, all within the lower portion of the Globigerinoides ruber Zone, and only where $G$. ruber is common or abundant. It is fairly common, however, in several of the samples where it was observed. The top of its range is coincident with that of $G$. obliquus at Site 225 , but somewhat lower at Site 228. Virtually all specimens are dextrally coiled. G. (G.) limbata is absent at Sites 227 and 229.

Globorotalia (Globorotalia) cf. praemiocenica (Plate 1, Figures 1-4)

This morphotype is similar to the holotype and paratypes of $G$. praemiocenica illustrated by Lamb and Beard (1972), differing primarily in the less convex dorsal surface (and hence less equal biconvexity), and the greater ventral inflation of many specimens. $G$. $(G.) \mathrm{cf}$. praemiocenica may be differentiated from $G$. $(G$.) limbata by the flatter dorsal side, the pronounced ventral inflation, and the absence of straightened "hockey-stick" (Blow, 1969) dorsal sutures. The appearance of this form in the Red Sea is somewhat surprising, in view of the Indo-Pacific affinities of the benthic fauna and the Caribbean provenance of $G$. praemiocenica s.s., but that species, if it is present in Indo-Pacific planktonic assemblages, has probably been reported as $G$. limbata or $G$. cultrata.

$G$. (G.) cf. praemiocenica is restricted to the three northern sites, and is present, with a single exception (Sample 227-3,CC), only within a short interval near the base of the Globigerinoides ruber Zone. It is sometimes relatively common. It was not recognized in the Arabian Sea (Leg 23A) or Gulf of Aden (E. Vincent, personal communication).

\section{Globorotalia (Hirsutella) hirsuta}

This form occurs only in a single sample $(1, \mathrm{CC})$ at Site 229 , where it is very rare.

\section{Globorotalia (Truncorotalia) crassaformis}

The noted occurrences of this species may include specimens attributable to $G$. (T.) crassula (of Blow, 1969). On the basis of the rare specimens observed in the Red Sea, no attempt was made to separate these forms. In view of their similarity in test shape and the "repetitive and heterochronous" (Blow, 1969) development of a carina, the validity of a specific, not to mention a subgeneric, separation of these two morphotypes seems doubtful to the author. G. (T.) crassaformis s.l. was observed only at Site 229 , where it is often present, although rare, in the top 140 meters (Core 10A) of recovered section. Below this horizon, occurrences of this species are rare and very isolated.

\section{Orbulina universa}

At the northern sites, the vertical distribution of $O$. universa is essentially coincident with the G. quadrilobatus Zone. Within this interval, specimens are generally rare to few; below, at all three sites, only extremely isolated occurrences of rare individuals were noted. In Holes 229 and $229 \mathrm{~A}$, this form is generally present and occasionally common, but appears somewhat less frequently below Core 12A. As a rule, its presence seems to be associated with that of $G$. quadrilobatus, and it may be that the two species have similar environmental tolerances.

\section{Pulleniatina obliquiloculata obliquiloculata}

This form was observed only in a few samples, as isolated juvenile individuals, at Site 229. $P$. obliquiloculata finalis was not encountered.

\section{Streptochilus tokelauae (= Bolivina tokelauae Boersma)}

Species of this genus have not been reported from Red Sea piston cores, largely because prior to the erection of this genus (Brönnimann and Resig, 1971) they were not recognized as planktonic forms, but also because they are quite uncommon in Late Quaternary sediments. $S$. tokelauae occurs as rare specimens in Samples 4,CC through Core 5, Section 3 (Globigerinoides quadrilobatus Zone) at Site 225 , and in a few isolated samples at Site 228 .

\section{Streptochilus globigerum (=Textilaria globigera Schwager)} (Plate 2, Figures 7-8)

S. globigerum is present only at two of the northern sites (225 and 227), and only within the Early Pliocene. In sediments at both locations, it occurs and is occasionally common in samples containing Globigerinita glutinata and Turborotalita "quinqueloba" assemblages, but it is occasionally present in isolated samples containing $G$. ruber.

\section{Turborotalia (Neogloboquadrina) dutertrei}

The distribution of $T$. (N.) dutertrei, which is found only at Site 229 , is somewhat similar to that of Globorotalia $(G$.) cultrata. It is present in most samples above Core $12 \mathrm{~A}$, usually rare but occasionally common, and is inconsistently present and rare below.

\section{Turborotalia (Turborotalia) pachyderma}

This normally cool-water form was observed only as rare specimens at Site 229, in Cores 4A through 7A. Virtually all specimens examined were dextrally coiled. Olsson (1973) has suggested that dextral forms of $T$. (T.) pachyderma should be referred to "Globorotalia pseudopachyderma" but other evidence (Bandy, 1972a, personal communication) appears to contraindicate the validity of this distinction.

Turborotalia (Turborotalia) sp. 1 (Plate 1, Figures 5-7; Plate 2, Figures 1-4)

This form appears to be unreported, and may represent a variant of $T$. (T.) humerosa or a primitive form of $T$. (N.) dutertrei. Neither of these alternatives seems very convincing, however, and $T$. $(T$.$) sp. 1$ has not yet been sufficiently studied to determine its affinities. 
The species occurs in a few samples at the northern sites, within the Globigerinita glutinata and Turborotalita "quinqueloba" zones. The most prominent occurrence is at Site 225 , where $T$. (T.) sp. 1 is present in most samples from Core 14 through Core 18, Section 2. Within this interval, it is present in most samples both with and without Globigerinoides ruber, and occasionally is the dominant form (e.g., Core 17, Section 1 and CC). Appearances are less frequent at the other northern sites, but occur in the same general stratigraphic position. This species was not observed in the Arabian Sea.

\section{Turborotalita "quinqueloba" ${ }^{2}$ (Plate 2, Figures 4-6)}

Very small, five-chambered forms similar in appearance to $T$. quinqueloba (Natland) are common in almost every sample containing planktonic foraminifera, and most authors who have studied Late Quaternary Red Sea samples have reported this species (presumably referring to the form observed and illustrated here). Comparison of the Red Sea specimens with the holotype illustration, and ecological studies of the modern distribution of $T$. quinqueloba s.s. from the Indian Ocean and other regions, strongly suggest, however, that the morphotypes observed here are not identical with Natland's taxon.

Turborotalita quinqueloba was first recognized from sea-floor samples collected offshore from Long Beach, California (as Globigerina quinqueloba, Natland, 1938) and is common in cool-water assemblages from that region (Kheradpir, 1970). The test is relatively small (maximum diameter of the holotype $=0.24 \mathrm{~mm}$ ) and is composed of five somewhat inflated subglobular chambers with a strongly lobulate periphery. The spiral surface is considerably flattened; the umbilical, slightly less so. The evolution and morphological variation of T. quinqueloba (Natland) have been discussed and illustrated by Parker (1962) and Asano et al. (1968). In the latter study, maximum test diameters were measured from four modern populations from the eastern and western Pacific Ocean. Average values for the four assemblages ranged from $0.180-0.214 \mathrm{~mm}$.

Most Red Sea specimens are considerably smaller than those reported by Asano et al. (1968). While measurements were not made directly, all specimens observed were smaller than $0.125 \mathrm{~mm}$ in diameter (based on sieve separations). The chambers are much more wedge-shaped, and less subglobular, than in the holotype, and the periphery is only slightly lobate. While it can be argued that these Red Sea specimens may represent juveniles, they do not resemble the ontogenetic stages dissected from modern specimens of T. quinqueloba (Asano et al., 1968), and these typical adult forms are not present. If specimens of $T$. quinqueloba s.s. resemble most closely Globigerina angustiumbilicata, the $T$. "quinqueloba" morphotype is closer in general test form and chamber shape to T. humilis (cf. Banner and Blow, 1960, pl. 8), although it possesses fewer chambers per whorl and lacks the pronounced umbilical flap.

Studies of the distribution of $T$. quinqueloba related to surface temperature in the Indian Ocean (Bé and Tolderlund, 1971; Boltovskoy, 1969) verify the conclusion reached in

\footnotetext{
${ }^{2}$ This has been named Globigerina Clarkei by Rögl and Bolli, DSDP, Leg 15 report; p. 563.
}

other major ocean basins (Table 2) that this species is primarily a cool-water inhabitant. The species has generally been reported from surface waters ranging in temperature from $1^{\circ}-28^{\circ}$, but is most abundant below $17^{\circ} \mathrm{C}$. The range $\left(27.6^{\circ} \mathrm{C}-29.2^{\circ} \mathrm{C}\right)$ reported by Beljaeva (1964)appears to be anomalous, but the size $(0.7 \mathrm{~mm})$ and morphology of her illustrated specimen suggest that it has been misidentified. The apparent optimum range is well below the temperatures prevalent in the Red Sea and Arabian Sea, where $T$. "quinqueloba" is abundant; because of its small size, it has probably not been collected in plankton tows in this region.

T. "quinqueloba" represents, in effect, an almost constant background element to the faunal populations; only in a very few samples containing other planktonic species is it absent, and this may be due to sorting. Usually this species is common or abundant. In some samples representative of the T. "quinqueloba" Assemblage, it is the only species present, but it sometimes occurs with Globigerinita uvula, Streptochilus globigerum, Globigerina cf. praebulloides, or Turborotalia sp. 1 as the only other faunal element. In the $T$. "quinqueloba" Zone at the northern sites the absolute abundance of this species within the sediment is not high, and it seems probably that the great relative abundance is due more to the absence of other species than to a faunal bloom of T. "quinqueloba."

\section{Planktonic Foraminiferal Paleoecology}

$$
\text { Northern Sites }(225,227,228)
$$

The only available basis for a reconstruction of Late Neogene climatic conditions in the Red Sea is the study of the environmental tolerances of living planktonic foraminiferal species, as deduced from modern populations. At the three northern sites, only eight such species are present in significant quantities in more than a very few samples: Globigerinoides ruber, G. quadrilobatus, G. conglobatus, Orbulina universa, Globigerinita glutinata, "Globigerina" rubescens rubescens, "G." tenella, and Turborotalita "quinqueloba." The last three species will not be considered further here, in the absence of reliable data concerning their distribution.

One of the important aspects of this fauna is that all of the species live primarily within the upper 100 meters of water; indeed, all (Jones, 1968) reach maximum abundance, where vertical distribution has been carefully studied, within the top 75 meters (Bé and Tolderlund, 1971, indicate a somewhat broader depth range for several of the species). Species living at slightly greater depths (e.g., Globorotalia cultrata) are rare or absent, but more common at Site 229 ; this is probably due to lower salinity tolerances of these forms and to the increase in salinity with depth at the northern sites. Deep water species, such as Sphaeroidinella dehiscens and Globorotalia truncatulinoides, are completely absent in the Red Sea; these forms are excluded from the basin by the shallow sill.

All recent studies of Red Sea planktonic faunas have concentrated on temperature and salinity as the environmental parameters controlling planktonic distribution, although these organisms certainly respond to other factors. This emphasis, however, appears to be justified as a basis for examination. While dissolved oxygen and food supply may influence their distribution in some oceanic regions, 
these parameters do not appear to approach limiting values in the Red Sea. Surficial waters are highly oxygenated because of the prevailing winds. Oxygen levels in the upper 100 meters at locations near Sites 225, 227, and 229 (Dietrich et al., 1966, Meteor stations 29 and 69) are comparable to those recorded in environments (Meteor stations 133 and 205) in the western and eastern Arabian Sea where planktonic foraminifera are particularly abundant (Zobel, 1971; 1973).

Organic nutrient levels in Red Sea surface waters were not examined. The relatively few studies on the nutritional requirements of planktonic foraminifera demonstrate clearly, however, that phytoplankton, including coccolithophorids, comprise a major element of the food supply (Ryther, 1969; Lipps and Valentine, 1970). The great abundance of nannofossils in virtually all samples containing planktonic foraminifera, and the high sedimentation rates calculated at all sites, imply that restrictions of food supply have not served as a restraint upon the planktonic populations.

Olausson (1960) examined the sediments in cores from the Mediterranean and Red seas. While foraminiferal data were presented for Mediterranean sites (based upon counts and interpretations by Parker, 1958 and Todd, 1958), no faunal analyses were performed, or climatic interpretations advanced, for Red Sea assemblages.

In the first modern study to investigate planktonic foraminiferal faunas in the Red Sea, Herman (1965) examined the distribution of 16 species in 14 cores spanning most of the length of the basin. Although she recognized the high salinity values prevailing in the Red Sea and the progressive increase in salinity with distance from the sill, the faunal fluctuations were interpreted entirely in terms of "cool" and "warm" assemblages alternating in response to glacial and interglacial episodes. The assignment of planktonic faunas to putatively temperature-dependent groupings was based largely on the ratio of "Globigerinoides ruber (eurythermal) to G. sacculifer (warm stenothermal), and of the pteropods Creseis acicula to Limacina inflata (thought to represent a similar temperature relationship). In more recent publications (Herman and Rosenberg, 1969; Herman, 1971) the role of salinity as a factor partially controlling the composition of Late Quaternary pteropod and foraminiferal faunas received greater emphasis.

Berggren and Boersma (1969) recognized faunal associations similar to those determined by Herman (1965), and used the same foraminiferal ratio ( $G$. ruber to $G$. sacculifer) as the foundation for their interpretations. On the basis of a discussion by Bé and Tolderlund (1971) of the climatic tolerances of these species, however, they interpreted the faunal changes primarily in terms of salinity, although an attempt was made to infer temperature fluctuations as well. The salinity changes were related to variations in sea level and correlated with the glacial sequence established for Europe. Meyer (1973) examined additional Red Sea piston cores. Unlike Berggren and Boersma (1969) he noted fluctuations in the distribution of smaller species, particularly Globigerinita glutinata and Turborotalita quinqueloba (=T. "quinqueloba"). The results, while somewhat inconclusive, suggest that species variations within the fine fraction (less than $125 \mu$ ) may have climatic implications similar to those observed among larger forms.

Although considerable effort has been expended in recent years in the study of the distribution of modern planktonic foraminiferal species from plankton tows, the environmental tolerances of these organisms are far from completely known. The applicability of the available evidence to the interpretation of Red Sea foraminiferal biofacies, however, is reduced by two basic difficulties. In the first place, primary emphasis in most plankton studies has been applied to the correlation of foraminiferal faunas with temperature conditions; where salinity has been examined, it has generally been considered a parameter of secondary importance. This is probably justified in most open-ocean studies, in view of the greater range of temperature than of salinity in the world's oceans. This approach, however, implicitly ignores the possibility of a complex interaction of these two parameters, particularly near the tolerance limits of a given species. It may prove, for example, that a particular species can tolerate a high level of salinity only when the prevailing temperature is below a critical level, lower than that which the species can tolerate at lower salinities. This possibility is of particular importance in the Red Sea, where very high salinities and seasonally high temperatures are known to exist, but could not be directly examined here.

Secondly, environmental conditions in the Red Sea at present are more severe than those examined in the available plankton tow studies; salinity values are above, and temperatures near, the upper limits observed in waters whose foraminiferal populations have been investigated. The only other significant marine basin exhibiting salinity values of this magnitude is the Eastern Mediterranean, but average surface temperatures there (Parker, 1958) are somewhat lower than at the Red Sea sites. Although plankton studies (Table 2) provide valuable information about the environmental tolerances and optima of Red Sea species, it is unsafe to extrapolate very far beyond the limits of the ecological conditions these authors report.

The sequence of faunal events observed in planktonic foraminiferal assemblages since the end of evaporite deposition in the Late Miocene may be considered in terms of an overall progression from less to more diverse faunas, with short-term fluctuations and variations superimposed on the general pattern. This pattern is reflected in the zonal sequence as defined earlier. Above the evaporites, the lowest foraminiferal faunas at all three northern sites are composed solely of benthic species. The earliest planktonic assemblages are essentially monospecific, consisting almost solely of Turborotalita "quinqueloba." In the overlying Globigerinita glutinata Zone, a second modern species, the nominate taxon, is present as well. Within both of these seqeunces, particularly at Sites 225 and 227 where they are present over an extended interval, there are numerous short-term incursions of Globigerinoides ruber and $G$. obliquus, but these species do not become established as permanent elements of Red Sea populations until the base of the $G$. ruber Zone in the Late Pliocene. Several species-notably Globigerina cf. praebulloides and Turborotalia $\mathrm{sp} .1$-are occasionally present during the lower two 
TABLE 2

Temperature and Salinity Tolerances of Selected Red Sea Planktonic Foraminiferal Species as Determined from Plankton Tow Studies

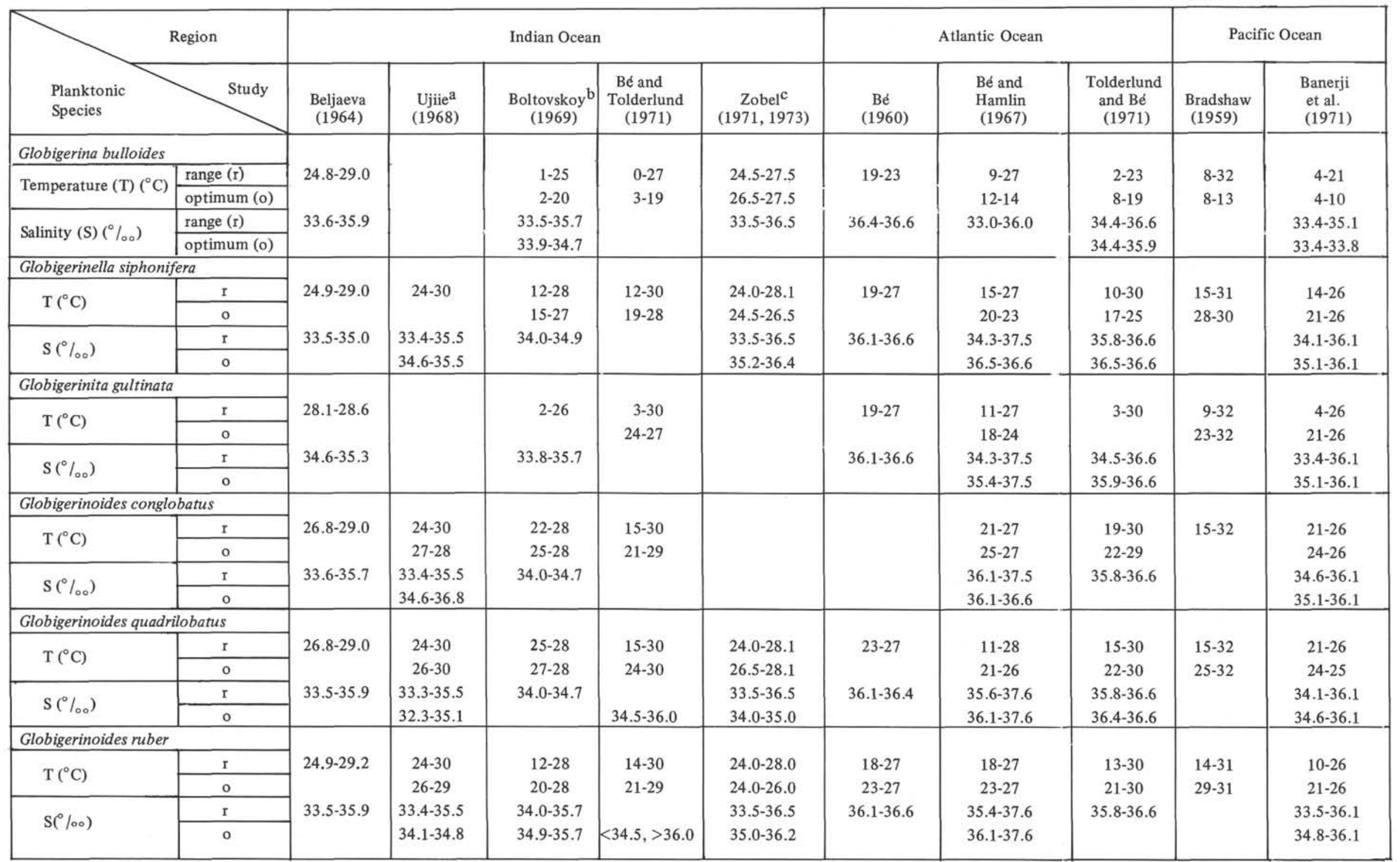


TABLE 2 - Continued

\begin{tabular}{|c|c|c|c|c|c|c|c|c|c|c|c|}
\hline \multicolumn{2}{|c|}{ Globorotalia cultrata } & \multirow{3}{*}{$24.9-29.2$} & \multirow{3}{*}{$24-30$} & \multirow{3}{*}{$\begin{array}{l}18-28 \\
20-28\end{array}$} & \multirow{5}{*}{$\begin{array}{l}16-30 \\
20-25\end{array}$} & \multirow{5}{*}{$\begin{array}{l}24.0-28.1 \\
24.0-26.5 \\
33.5-36.5 \\
35.0-36.1 \\
\end{array}$} & \multirow{3}{*}{$23-27$} & \multirow{3}{*}{$\begin{array}{l}18-28 \\
21-24\end{array}$} & \multirow{3}{*}{$17-30$} & \multirow{5}{*}{$\begin{array}{l}15-32 \\
24-32\end{array}$} & \multirow{3}{*}{$21-26$} \\
\hline \multirow{2}{*}{$\mathrm{T}\left({ }^{\circ} \mathrm{C}\right)$} & $\mathrm{r}$ & & & & & & & & & & \\
\hline & o & & & & & & & & & & \\
\hline \multirow{2}{*}{$\mathrm{S}(\%)$} & $\mathrm{r}$ & \multirow[t]{2}{*}{$33.5-35.7$} & $33.3-35.5$ & $34.0-35.6$ & & & $36.1-36.4$ & $36.5-37.5$ & $35.8-36.6$ & & $34.6-36.1$ \\
\hline & o & & $34.6-35.3$ & $34.0-35.4$ & & & & & & & \\
\hline \multicolumn{2}{|c|}{ Orbulina universa } & \multirow{3}{*}{$10.9-29.0$} & \multirow{5}{*}{$\begin{array}{c}24-30 \\
24-26 \\
33.3-35.5 \\
34.6-34.8\end{array}$} & \multirow{3}{*}{$8-28$} & \multirow{5}{*}{$\begin{array}{l}10-30 \\
17-23\end{array}$} & & & & & & \\
\hline \multirow{2}{*}{$\mathrm{T}\left({ }^{\circ} \mathrm{C}\right)$} & $\mathrm{r}$ & & & & & $24.8-28.1$ & $19-27$ & $12-28$ & $11-30$ & $11-32$ & $10-26$ \\
\hline & o & & & & & $27.4-28.0$ & $23-27$ & $18-24$ & $18-30$ & $11-25$ & \\
\hline \multirow{2}{*}{$\mathrm{S}(\%)$} & $\mathrm{r}$ & \multirow[t]{2}{*}{$33.5-35.9$} & & \multirow[t]{2}{*}{$34.3-34.9$} & & $33.6-36.3$ & $36.1-36.6$ & $34.3-37.5$ & $35.8-36.6$ & & $33.4-36.1$ \\
\hline & o & & & & & $34.5-35.2$ & & $35.4-37.5$ & & & \\
\hline \multicolumn{2}{|c|}{ Turborotalita quinqueloba ss. } & \multirow{5}{*}{$27.6-29.2$} & & \multirow{5}{*}{$10-12$} & & & & & & & \\
\hline \multirow{2}{*}{$\mathrm{T}\left({ }^{\circ} \mathrm{C}\right)$} & $\mathrm{r}$ & & & & $1-21$ & & & $9-20$ & $2-22$ & $8-28$ & $4-21$ \\
\hline & o & & & & $1-12$ & & & $12-15$ & $5-11$ & $12-17$ & $4-10$ \\
\hline \multirow{2}{*}{$\mathrm{S}(\%)$} & $\mathrm{r}$ & & & & & & & $33.2-36.0$ & $34.4-36.0$ & & $33.4-35.1$ \\
\hline & 0 & & & & & & & $33.4-35.8$ & $34.4-35.0$ & & $33.4-33.8$ \\
\hline
\end{tabular}

${ }^{\mathrm{a}}$ From Nasu and Shimano, 1966.

${ }^{b_{F}}$ From Discovery Reports, Cambridge, 1957, v. 28.

From Dietrich et al., 1966. 
zones, and others-Globorotalia limbata and $G$. cf. praemiocenica-during the Globigerinoides ruber Zone. In general, however, there is only one species consistently present in the $T$. "quinqueloba" Zone, two in the G. glutinata Zone, and six in the $G$. ruber Zone (the consistent additions to underlying faunas include $G$. ruber, $G$. obliquus, "Globigerina" rubescens rubescens and "G." rubescens decoraperta). While $G$. obliquus and " $G$." rubescens decoraperta disappear near the end of the Pliocene, the final additions to the fauna appear consistently in the following order: Globigerinoides quadrilobatus, Orbulina universa, Globigerinella siphonifera, "Globigerina" tenella, Globorotalia cultrata (at Site 228 only), and Globigerinoides conglobatus.

If the short-term fluctuations observed at all three sites are temporarily ignored, it can thus be seen that a progressive increase in diversity appears throughout the northern sequences. Several lines of evidence suggest that the environmental parameter controlling this faunal pattern is decreasing salinity rather than decreasing temperature.

In the first place, it is difficult to visualize a mechanism for the progressive decrease, throughout the Late Noegene, in surface temperature in the Red Sea. Although climatic deterioration is widely recognized as an element of Pleistocene paleoecology, the effect was most intense and yet cyclical during periods of Pleistocene glaciation. The most striking faunal changes in the Red Sea sequences, however, occur near the base of the Late Pliocene and during the Early Pleistocene. While the former would appear to be a time of relative cooling, although not as intense as the Late Pleistocene (cf. the Pliocene climatic curves of Ciaranfi and Cita, 1973), the Early Pleistocene has been recognized as a period of somewhat increased temperature in the Mediterranean region (Selli, 1967; Cita et al., 1973) and elsewhere (Bandy et al., 1971). No reflection of Early Pleistocene faunal deterioration was observed at the northern sites.

Temperature conditions in the Red Sea are largely independent of those in the Indian Ocean; the benthic foraminiferal data indicate, however, that this basin has been the source of Red Sea water throughout the Late Neogene. Surface water temperatures are controlled by insolation in the Gulf of Aden and Red Sea, and by wind conditions and evaporation (Patzert, 1972) in the Red Sea. Temperatures at the Straits of Bab-El-Mandeb are approximately $.3^{\circ} \mathrm{C}$ higher than at the mouth of the Gulf (Dietrich et al., 1966, Meteor stations 62 and 92). Because the Red Sea is located within the subtropical climatic belt, it seems unlikely that major progressive changes in insolation have occurred during the Late Neogene.

Finally, if temperature were the primary controlling parameter, it would be anticipated that diversity would decrease during warmer, postglacial conditions. Berggren (1969), however, found that diversity and foraminiferal abundance increased, rather than decreased, across the Pleistocene-Holocene (zone B-zone A) boundary. While temperature changes may have influenced the faunal content of Red Sea assemblages to a minor degree, particularly with respect to small-scale fluctuations in faunal content, modifications of sea-surface temperature do not seem to account for the observed progressive increase in planktonic foraminiferal diversity.
In contrast, salinity changes can reasonably account for a number of the observed faunal events; salinity control of the distribution of several modern species in the Red Sea can be demonstrated. A brief account of temperature and salinity values at the northern sites, however, is in order.

At Sites 225 and 227, the average yearly surface temperature is approximately $28.3^{\circ} \mathrm{C}$, and the range is from $25^{\circ} \mathrm{C}$ (in February) to $31^{\circ} \mathrm{C}$ (July through September). Salinity is essentially constant, near $39 \%$, except during August and October (approximately $39.5 \%$ ). The temperature and salinity patterns at Site 228 are similar, but the former is somewhat higher (average $29.1^{\circ} \mathrm{C}$, range $27^{\circ} \mathrm{C}$ to $\left.31^{\circ} \mathrm{C}\right)$ and the latter slightly lower $(38.5 \%$, increasing to $39.0 \%$ in late summer) because of lower wind velocities at this latitude. At Site 229 , the average temperature is $28.5^{\circ} \mathrm{C}$, ranging from $25^{\circ} \mathrm{C}-32^{\circ} \mathrm{C}$. Salinity is somewhat variable, depending in great part upon the seasonal variation in current patterns. From January to June, values are essentially constant at $36.8 \%$, but increase to $38.0 \%$ in October and $37.5 \%$ in November. It should also be noted that an increase in salinity and a decrease in temperature also occur with depth within the surficial water. At 100 meters, yearly temperatures range from $18^{\circ} \mathrm{C}-24+{ }^{\circ} \mathrm{C}$ at Site 229 and are nearly constant at $24^{\circ} \mathrm{C}$ at the northern sites; salinities at the southern site range from $37-39 \%$ and average $40 \%$ farther north.

Three planktonic species are presently distributed over only limited parts of the Red Sea. Globigerina bulloides is common at Site 229 and essentially absent at the northern sites (a similar distribution was noted by Herman, 1965, from piston cores); Globorotalia cultrata is common at the southern site, rare at Site 228, and absent farther north. Because the surface temperature is essentially the same in both northern and southern areas-in fact, slightly higher at Site 229 than at Sites 225 and 227-and the subsurface temperatures are all within the recorded range of both taxa, it appears that Globigerina bulloides is restricted to salinities less than $37-38 \%$, and Globorotalia cultrata to less than $38-38.5 \%$. The great rarity of $G$. cultrata below Core 5 at Site 228 and its absence below Core 11 appear to reflect higher salinities at Site 228 during the Late Pleistocene.

Similar considerations apply to the distribution of Globigerinoides conglobatus. This species is rare in most samples at all sites. Herman (1965) reported it as present but rare at most locations south of $25^{\circ} \mathrm{N}$, and as absent in surface sediments in Cores V14-124 and V14-125 farther north. This latitude roughly corresponds to the position of the $40.0 \%$ isohaline (Patzert, 1972). Because the average and maximum temperatures at $25^{\circ} \mathrm{N}$ are lower than in surficial waters farther south and well within the reported tolerances of this form, it is proposed that the absence of $G$. conglobatus results from its inability to survive salinities in excess of approximately $40 \%$. This species is the last element of the modern fauna to appear in Red Sea sediments and is effectively restricted to the upper part of the Globigerinoides quadrilobatus Zone (late Early Pleistocene to Holocene). In view of its modern Red Sea distribution, it appears very likely that the absence of $G$. conglobatus prior to this time was due to excessive salinity. 
Globigerinoides quadrilobatus is considerably less common in the lower part of its range than in the upper. In the earlier horizons of the G. quadrilobatus Zone, G. ruber is much more abundant. Bé and Tolderlund (1971) and Berggren and Boersma (1969) have discussed the environmental relationship of these two forms. While both are warm-water species, the temperature tolerances of $G$. quadrilobatus are, if anything, slightly higher than those of G. ruber; the latter, however, is more abundant in surface waters whose salinity exceeds $36 \%$ than the former. The transition, therefore, from $G$. ruber Zone faunas to populations in upper Pleistocene and Holocene sediments with abundant $G$. quadrilobatus probably represents a decrease in Red Sea surficial water salinity.

The explanation for faunal events in the Pliocene sequences is more difficult to derive; the environmental restrictions on the living species are not known, and no direct evidence can be obtained from those that are now extinct. The upper Miocene evaporite deposits, however, certainly indicate very highly saline surface waters. The absence of planktonic species immediately above the evaporites (probably not due to postdepositional test destruction because of the presence of benthic foraminiferal tests in a number of Early Pliocene samples containing no planktonic species) and the subsequent appearance of a monospecific planktonic fauna probably reflect high surface salinity during the earliest Pliocene. Finally, the presence of Globigerina cf. praebulloides in low-diversity Globigerinita glutinata Assemblages in the Early Pliocene (e.g., Site 227, Core 5, Sections 1, 2 and Core $12, \mathrm{CC}$ ) suggests relatively low surface temperatures. While the environmental preferences of this form are not known with any degree of certainty, it has been reported (Bandy, 1972b) from faunas characterized by cool-water associations. The highly restricted assemblages in which it occurs would therefore not appear to represent high temperature conditions.

The overall trend of environmental change in the Red Sea since the Late Miocene appears to be a progressive, if not necessarily uniform or linear, decrease in surficial water salinity, with numerous and sometimes significant fluctuations of relatively short duration. It is tempting, and perhaps not overly simplistic, to attribute this broad trend to a progressive increase in surficial water inflow from the Gulf of Aden as a result of the tectonic sinking of the sill, and the fluctuations to changes in such environmental parameters as wind patterns and velocities, evaporation rates, precipitation and river discharge, surface temperature, and sea level.

The Red Sea evaporite sequence is strikingly similar, in both lithology and time of formation, to the anhydrite and halite deposits recently discovered by DSDP Leg 13 in the Mediterranean Sea. The Mediterranean evaporites have been interpreted (Nesteroff, 1973; Hsü et al., 1973) as a shallow-water facies, but no direct evidence bearing on Late Miocene water depth is provided by Red Sea foraminiferal assemblages. If the Mediterranean depositional model is accepted (Hsü et al., 1973) in place of the deep-water model for evaporite genesis (Schmalz, 1969), the Red Sea must have been more or less completely isolated from the Mediterranean Sea and the Gulf of Aden during the Late
Miocene. Overtopping of the southern sill near the beginning of the Pliocene would have led to relatively rapid filling of the Red Sea basin; there is, again, no direct evidence from the foraminifera whether the physiographic basin at that time was as deep as it is at present.

If inflow from the Gulf of Aden had rapidly reached its present value, it is difficult to understand why the modern Red Sea planktonic fauna was not immediately established. Inflow at the Straits of Bab-El-Mandeb for a given sea level is primarily controlled by two factors-width of the straits and depth of the sill; evaporative loss represents at present only a small fraction of, with correspondingly little impact on, inflow volume (Patzert, 1972).

Limited separation of Africa and Arabia must have occurred during or prior to the Early Pliocene, as indicated by the presence in early postevaporite sediments of benthic foraminiferal faunas whose source was the Gulf of Aden and Indian Ocean. On the other hand, the presence of relatively undeformed Miocene evaporites at the margin of the axial trough (i.e., at Sites 225 and 227)indicate a period of quiescence (nonspreading) between the Late Miocene and the time of initiation of this axial feature. If additional widening has been caused by this subsequent episode of plate divergence, an approximate indication of timing can be obtained from the geologic relationships observed at Site 229. At this locality, unpublished seismic data indicate that the axial trough is buried beneath some 500 meters of younger sediment (Chapter 19). Extrapolation from the minimum sedimentation rate calculated for the Late Pleistocene at this Site (Chapter 19, this volume) yields an estimated age of 750,000 years for the age of igneous basement, a minimum age for the onset of the present phase of separation.

Published estimates of Red Sea spreading rates $(1 \mathrm{~cm} / \mathrm{yr}$., Vine, 1966) are probably based upon erroneous assumptions of spreading patterns and timing; nonetheless, this rate is moderately slow in comparison to those calculated for other oceanic ridge systems. As the width of the axial trough near Site 229 is no more than about $40 \mathrm{~km}$ (Lowell and Genik, 1972), the maximum age for the onset of spreading is unlikely to be much greater than $1.2 \mathrm{~m} . \mathrm{y}$., unless spreading rates have been much lower than assumed here. The recent initiation of plate separation in the Red Sea is also indicated by the very thin sediment layer observed within the axial trough at Site 226 , an indication as well that late-stage spreading has not been extremely slow. This evidence suggests that post-Miocene plate divergence, and widening of the straits, did not begin until middle Early Pleistocene, a time at which the planktonic foraminiferal evidence indicates that surficial water salinity had nearly reached its modern values. Widening of the straits thus appears to have had relatively little effect on surface salinities, and the depth of the sill has been the primary factor controlling inflow, particularly during the Pliocene and Early Pleistocene. The high Early Pliocene surface salinity, and the progressive decrease in salinity levels throughout most of the Late Neogene, can thus be attributed to a depression of the southern sill and a corresponding increase in the surface water contribution from the Gulf of Aden. 
It should be noted that the range of salinity values represented by the suites of planktonic faunas is probably quite small. Although the maximum salinity tolerances for planktonic foraminifera, and for Turborotalita "quinqueloba" in particular, are unknown, it is unlikely that these forms can tolerate levels higher than $50 \%$. Indeed, the maximum value is probably lower than this arbitrary number, possibly considerably lower $(42.5 \%$ ) if the absence of planktonic species in the Gulf of Suez (Said, $1950 \mathrm{~b}$ ) is due to salinity rather than inadequate depth. In any case, it is probable that the Early Pliocene and modern central Red Sea surface salinities have differed by no more than 5 to 10 parts per thousand.

Significant changes in surface salinity, in terms of their effect on the planktonic faunas, have almost certainly been affected by a wide variety of factors other than sill depth and the width of the straits. Slight variations in the rate of evaporation, with resultant effects on the salinity and temperature of surface waters, would result from modifications in the velocity of winds along the length of the Red Sea, from changes in cloud cover or from variations in prevailing atmospheric temperatures. Fluctuations in precipitation and river discharge may have occurred in this region during the Late Neogene, although whether either source is likely to have contributed sufficient water to the surficial layers to significantly modify surface salinities remains doubtful (R. Coleman, personal communication). Finally, eustatic changes in sea level have periodically modified inflow over the sill, resulting in occasional episodes of basinal isolation (Berggren and Boersma, 1969; Meyer, 1973).

These variations in climatic and oceanographic conditions, however, are more likely to have been episodic than progressive and are probably responsible for the numerous short-duration fluctuations in faunal content. While these episodes represent important events in the history of Red Sea foraminiferal faunas, it is not feasible in view of the limitations on the data presently available to attempt analysis of the records of the short-term climatic changes at this time.

\section{Southern Site (229)}

The extremely high rates of sedimentation (270 to 1250 $\mathrm{m} / \mathrm{m} . \mathrm{y}$.) calculated for the deposits at Site 229, and the high percentage of filled or recrystallized tests in otherwise well-preserved faunas within the lower half of the recovered section, clearly indicate major elements of transport and reworking at this location. Because the reworked tests could not be consistently recognized and differentiated, the foraminiferal data do not at this time justify a detailed interpretation of paleoecological trends.

Nannofossil age determinations (Chapter 19, this volume) place the entire sequence recovered at Site 229 within the Late Pleistocene, and most samples include planktonic foraminiferal assemblages containing common Globigerinoides quadrilobatus. The faunas are more diverse than those observed at the northern sites; the additional species present include Globorotalia (Truncorotalia) crassaformis, Turborotalia (Neogloboquadrina) dutertrei, T. (T.) pachyderma, Pulleniatina obliquiloculata, and common Globigerina bulloides. The increased diversity is probably a response to the lower salinity here as opposed to the northern sites (temperature levels are essentially comparable), although some of the tests of these species may represent the transported remains of specimens killed by increased salinity at the sill. Such postmortem transport within the water column, however, is unlikely. Berger and Piper (1972) have calculated an average settling velocity of $2.3 \mathrm{~cm} / \mathrm{sec}$ for tests in the size range of these species (greater than $250 \mu$ ). At this velocity, the tests could settle through the northward-flowing winter surface layer $(50 \mathrm{~m})$ in 0.6 hours. If the maximum measured surface velocities $(80 \mathrm{~cm} / \mathrm{sec}$; Siedler, 1968) prevailed between the straits and Site 229, the tests would be transported less than $2 \mathrm{~km}$ northward while sinking through the surface layer. This calculation neglects the effect of turbulence in the surface water, but the correction is probably offset by the southward transport as the tests sink through the intermediate layer outflow current. Transport during descent through the apparently slow-moving deep water is probably negligible. Northward transport of dead tests is therefore unlikely to exceed a few kilometers, considerably less than the distance $(120 \mathrm{~km})$ between the location of minimum sill depth (Hanish Island) and Site 229. It should be noted, however, that Boltovskoy and Lena (1970), on the basis of indirect evidence, have proposed much longer settling times for dead planktonic foraminifera.

The most distinctive faunal changes observed in Holes 229 and 229A occur between Cores 12A and 16A. G. quadrilobatus is less common below than above this interval, and its lower occurrences are somewhat sporadic. The same is true for Globigerinella siphonifera, Orbulina universa, Globorotalia cultrata, and the species, described above, which are not found at the northern sites. This change suggests a period of slightly increased salinity and may correspond to a prolonged low stand of sea level associated with a period of major glaciation. No attempt at direct correlation will be made here, but the greatly expanded Late Pleistocene sequence may permit the relation of Red Sea events to climatic episodes elsewhere associated with glacial cycles, providing that the sill has been essentially stationary over this short $(300,000$ years) interval and that reworked faunas can be consistently recognized.

\section{BENTHIC FORAMINIFERA}

The benthic foraminiferal faunas of the Red Sea are not well known, and have received relatively little attention in most previous studies. The most comprehensive examination (Said, 1949; 1950a; 1950b) was limited to the northernmost Red Sea and Gulfs of Suez and Aqaba. Said related the benthic species to water depth, but concluded (1950b) that nitrogen content of the bottom sediments exercised primary control over species distribution. He recognized that most of the benthic species in his samples were typical of Indo-Pacific faunas, but interpreted the presence of two Atlantic-Mediterranean forms-Cibicides rhodiensis and C. gibbosa-as indicative of a "former Pliocene seaway between the Mediterranean and Red Sea" (Said, 1949, p. 3). Herman (1965) noted the presence of benthic species, particularly Uvigerina hollicki, but did not comment on their distribution, except to note the presence 
of apparently displaced faunas. Meyer (1973) studied in detail the benthic foraminifera in several piston cores from locations near Sites 225 and 227. Based on the interpreted upper depth limits of the observed species, he concluded that virtually all specimens probably represented transported assemblages and that no indigenous benthic populations existed below 500 meters.

Two generally distinct assemblages of benthic foraminifera were recognized in Leg 23B cores, although a number of species are common to both. The association which occurs stratigraphically higher at all three northern sites and which is present throughout the recovered interval at Site 229 is termed the Uvigerina tenuistriata Assemblage, although no single species is consistently present or dominant. At the northern sites this assemblage is nearly coincident with the Globigerinoides quadrilobatus Zone, but its first appearance is slightly older than the base of that zone at Sites 225 and 228. The relatively common species typical of this assemblage include:

Uvigerina tenuistriata Reuss (probably $=U$. hollicki of Herman, 1965)

Sphaeroidina bulloides d'Orbigny

Ehrenbergina cf. bradyi Cushman

Astrononion fijiensis Cushman and Edwards

Bolivina nitida Brady

Angulogerina angulosa (Williamson) (= Uvigerina angulosa Williamson)

Uvigerina auberiana d'Orbigny

Triloculina $\mathrm{cf}$. trigonula (Lamarck) (= Miliolina trigonula Lamarck)

Benthic foraminifera are usually rare in Red Sea samples containing the Uvigerina tenuistriata Assemblage, except at Site 229.

The stratigraphically lower Hanzawaia topanoeliensis Assemblage is the first foraminiferal population to appear above the evaporites. The nominate species is present, and usually common, in most samples containing this benthic fauna, and the highest horizon containing the assemblage is tentatively recognized on the latest occurrence of this species. The taxa typical of the $H$. topanoeliensis Assemblage and not co-occurring with the $U$. tenuistriata Assemblage faunas include:

Hanzawaia topanoeliensis (LeRoy) (= Cibicides topanoeliensis LeRoy $=H$. concentrica of Zobel, 1973)

Cibicorbis koeboeensis (LeRoy) (= Cibicides koeboeensis LeRoy)

Uvigerina cf. striatella Reuss (= Uvigerina $\mathrm{sp}$. of Zobel, 1973, pl. 2, fig. 18)

Bolivina amygdalaeforme Brady

?Coryphostoma limbata (Brady) (= Bolivina limbata Brady)

Planorbulinella larvata (Parker and Jones) (= Planorbulina vulgaris larvata Parker and Jones)

Baggina inflata LeRoy

The typically high relative abundances of this association may be due to somewhat lower numbers of planktonic specimens below the Globigerinoides quadrilobatus Zone.

Among the relatively few species present, and frequently common, in both assemblages are the following:

Cibicides mahabethi Said
Cassidulina sp. 1 (= Cassidulina laevigata of Zobel, 1973)

Cancris auriculus (Fichtel and Moll) (= Nautilus auriculus Fichtel and Moll)

Hanzawaia cf. rhodiensis (Terquem) (= Truncatulina rhodiensis Terquem)

Anomalina colligera Chapman and Parr

Gyroidina sp. (= Gyroidina sp. of Zobel, 1973, pl. 2, figs. 51-52)

Pseudoeponides cf. equatorianus (LeRoy) (= Rotalia equatoriana LeRoy $=P$. pauciloculata of Zobel, 1973)

Bolivina cf. catanensis Seguenza

The absence of benthic forms from horizons immediately above the evaporites at Sites 227 and 228 appears to be due to poor preservation rather than to an unsuitable biological environment.

Two aspects of the species associations are of special importance with respect to Late Neogene conditions in the Red Sea. All of the taxa listed above, as well as additional less common species not enumerated here, are characteristic of relatively shallow water-lower neritic, and perhaps upper bathyal, depths. A detailed examination of depth limits is not justified in view of the incompleteness of data and the uncertainties of identification at the present level of study, but no species observed is characteristic of water depths greater than perhaps 200-300 meters (Bandy, 1960). Where these species have been reported in open-ocean studies (e.g., Zobel, 1973), the forms listed above are typical of depths between 50 and 200 meters.

The depths at which the core samples were taken are, of course, considerably greater (Table 1). Any of three possible explanations could account for this apparent anomaly. It is unlikely, to eliminate the first explanation, that the relatively shallow species indicate shallow paleodepths and a recent deepening of the Red Sea. The highest samples observed at all stations contain these species, and similar depth interpretations have been made from piston-core-top sediments from equivalent depths (Meyer, 1973). It is possible, however, that (1) conditions within Red Sea deep waters are unsuitable for any benthic species to exist, and the observed faunas are thus transported elements from shelf depth; or (2) because temperatures at these depths in the Red Sea are considerably higher than in normal oceanic conditions, typically shallow-dwelling benthic species have been able to live at considerably greater depths than in unsilled basins elsewhere. The data are insufficient, at present, to choose between these hypotheses. The reason for the change in benthic faunas is similarly obscure. Because of the similarity in paleobathymetric implications between the two assemblages and the near coincidence of the transition with the Globigerinoides quadrilobatus Zone-G. ruber Zone boundary, it may reflect a response to changes in salinity.

While all forms observed in the Red Sea have also been reported from Indo-Pacific region samples, most are not present in the Mediterranean. The latter group includes Anomalina colligera, Planorbulinella larvata, Bolivina nitida, B. amygdalaeforme, Baggina inflata, Astrononion fijiensis, Hanzawaia topanoeliensis, and Cibicorbis koeboeensis. In contrast, none of the species are restricted to the Atlantic-Mediterranean faunal province. The forms reported by Said (1949) from the Red Sea and by Parker 
(1958) from the Mediterranean as Hanzawaia (or Cibicides) rhodiensis are not identical with the holotype. Terquem specifically reported the absence of a carina on his specimen, a feature conspicuously present on the forms illustrated by these two authors. In any case, the author has observed specimens identical with the Mediterranean and Red Sea forms (H. cf. rhodiensis), as well as of Bolivina cf. catanensis, another "typical" Mediterranean species, in samples from a turbidite in the Arabian Sea (Sample $223-2-6,96-98 \mathrm{~cm}$ ), and in samples from the continental shelf off the coast of Hong Kong, South China Sea. These species, therefore, are not restricted to the AtlanticMediterranean province.

The Red Sea faunas bear a strong similarity to assemblages reported from a number of Indo-Pacific regions. These include: Arabian Sea (Zobel, 1973), Andaman Sea (Frerichs, 1970), East Indies (LeRoy, 1941; 1944), and to a lesser extent, Okinawa (LeRoy, 1964). Many of the species have been recorded from other regions in the Pacific Ocean as well (Barker, 1960, Cushman, 1910-1917, 1932-1942; Cushman et al., 1954; Todd, 1965). There is little or no correspondence between any Red Sea faunas and the Quaternary shallow-water faunas from the Egyptian Mediterranean coast (Said and Kamel, 1956; 1957; Said and Basiouni, 1958). In view of the faunal relationships, it must be concluded that no evidence exists for any interconnection between the Red Sea and Mediterranean Sea since the end of evaporite deposition, although Heybroek (1965) has indicated that prior to this time the benthic faunas were of Mediterranean affinity.

\section{MICROFOSSILS OTHER THAN FORAMINIFERA}

\section{Pteropods}

The presence and distribution of pteropod species in the Red Sea have been noted and studied by a number of authors (Herman, 1965; 1971; Chen, 1969), but a detailed examination has not been attempted here. Pteropod shells are present as well-preserved and unaltered fossils at the northern sites only in the upper part of the Globigerinoides quadrilobatus Zone, where they were sometimes common (e.g., Site 228, Core 1) but only sporadically observed. At lower horizons, they are occasionally found as elements of lithified fragments or as casts or molds. These forms occur slightly more frequently at Site 228 than at Sites 225 and 227 , but are absent from most samples at all northern drilling locations.

Pteropods are consistently present, and often common, in Cores 1 through 7A at Site 229, but are generally absent below.

\section{Otoliths}

Otoliths are conspicuous (because of their size relative to foraminifera) but relatively rare elements of a number of isolated samples throughout the interval recovered at Site 229. No attempt was made to identify the species present.

\section{Unidentified Microfossils}

A few samples in each of the holes at all three northern sites contain significant numbers of a small calcareous form (Plate 2, Figures 9-10) whose identity and nature are unknown. It consists of a small sphere surmounted by a roughly conical projection. The specimens are solid and react rapidly and completely with hydrochloric acid. These forms are common at some horizons, and occasionally (e.g., Sample 225-15-2, 40-51 $\mathrm{cm}$ ) completely dominate the washed residues of individual samples. Their distribution appears to be completely unrelated to the foraminiferal faunas with which they are associated, and it seems probable that they have been transported from shallower depths.

\section{DESCRIPTION OF CORES}

\section{Site 225}

The Globigerinoides quadrilobatus Zone extends at this site from the surface through Core 9, Section $5(0-61 \mathrm{~m})$, although minor occurrences of $G$. ruber Assemblage faunas are present in Samples 4-5, 76-78 cm (26 m) and 9-3, 51-53 $\mathrm{cm}(57 \mathrm{~m})$. No nannofossil or foraminiferal zones are missing, but the sedimentation rate curve (Chapter 15, this volume) suggests that an unconformity may be present near the base of the $G$. quadrilobatus Zone. The absence of a significant interval of alternation between $G$. quadrilobatus and $G$. ruber Assemblage faunas, observed near this horizon at Site 228, and the relative shortness of the G. ruber Zone and Discoaster brouweri (nannofossil) Zone support but do not prove this assertion. G. conglobatus is essentially absent below Core $4(27 \mathrm{~m})$, and the range of Globigerinella siphonifera is coincident with that of the G. quadrilobatus Zone.

The G. ruber Zone occupies Cores 10 through 13 (63-86 $\mathrm{m})$; the highest occurrence of this zone approximately corresponds to the initial appearance of Orbulina universa and the disappearance of "Globigerina" rubescens decoraperta, Globigerinoides obliquus, Globorotalia limbata, G. cf. praemiocenica, and the Hanzawaia topanoeliensis benthic fauna. At a few horizons in this zone, $G$. quadrilobatus is present, but this species is common only in Sample 11-5, $47-49 \mathrm{~cm}(75 \mathrm{~m})$.

Cores 14 and $15(86-104 \mathrm{~m})$ represent the Globigerinita glutinata Zone. The nominate species and Turborotalita "quinqueloba" are the only species present in significant numbers, and most of the species present in the G. ruber Zone are absent below Core 14 .

In Cores 16 through $19(104-140 \mathrm{~m})$, an interval assigned to the $T$. "quinqueloba" Zone, no consistent character can be ascribed to the faunas. Most populations are dominated by $T$. "quinqueloba;" $G$. ruber and $G$. obliquus are common in several samples-Samples 16-2, $52-54 \mathrm{~cm}(106 \mathrm{~m})$ and $17-4,46-48 \mathrm{~cm}(118 \mathrm{~m})$-and Globigerinita glutinata in others. Turborotalia sp. 1 is present in most samples of Cores 16 and 17 (and is common within Core 17); Streptochilus globigerum is common in many of the samples from Cores 18 and 19 , as well as within Core 22 . This stratigraphic interval appears to represent a period of instability and rapid fluctuations in faunal content and surface water conditions.

Turborotalita "quinqueloba" is the only species present in the minor planktonic faunas of Cores 20 through 22 (140-167 m), except for occasional appearances of Streptochilus globigerum. Preservation, generally good 
above, is fair or poor; most specimens in many of the samples are filled and occasionally crushed.

Rare to few benthic foraminifera typical of the $H$. topanoeliensis Assemblage are present in samples from Core 24 , but no specimens were observed below this horizon within the evaporites.

\section{Site 227}

Cores 1 and $2(0-27 \mathrm{~m})$ contain planktonic populations typical of the Globigerinoides quadrilobatus Zone, although $G$. conglobatus is absent. Pteropods are particularly common in Core 1.

A major unconformity, indicated by both foraminiferal and nannofossil zonations, occurs between Cores 2 and 3, and the remaining recovered interval includes a considerably expanded Early and early Late Pliocene section.

Cores 3 through $6(27-48 \mathrm{~m})$ are assigned to the Globigerinita glutinata Zone; the G. ruber Zone is absent, although $G$. ruber, $G$. obliquus, and Globigerina cf. praebulloides are sporadically present, and occasionally common (notably in Cores $5(36-38 \mathrm{~m}$ ) and Sample 10,CC $(75 \mathrm{~m})$ as low as Sample 20,CC (155 m). Fluctuations in species content are common in samples from Cores 7 through $12(54-83 \mathrm{~m})$, but this interval, as well as the remainder of the planktonic faunas, is assigned to the $T$. "quinqueloba" Zone. Most faunas are dominated by this species, commonly co-occurring with Streptochilus globigerum; isolated occurrences of Globigerinoides obliquus, Globigerinita glutinata, and Turborotalia sp. 1 testify to Early Pliocene fluctuations of sea-surface oceanography. Planktonic foraminifera are generally absent below Sample 22,CC $(164 \mathrm{~m})$, although a single occurrence of $T$. sp. 1 appears [Sample 36,CC $(286 \mathrm{~m})$ ] within the evaporite sequence.

Benthic foraminiferal species typical of the $U$. tenuistriata Assemblage are present, but rare, in Cores 1 through 3 . The remaining samples through Core 27 (205 $\mathrm{m})$, as well as Sample $36, \mathrm{CC}$, contain generally common faunas of the $H$. topanoeliensis Assemblages. Preservation is generally poor below Sample 23,CC (168 m).

\section{Site 228}

In contrast to the stratigraphy at Site 227, the Late Pliocene and Quaternary interval is much expanded at Site 228, and the Early Pliocene section is quite short. The Globigerinoides quadrilobatus Zone extends from Core 1 through Core $16-3,60-62 \mathrm{~cm}(0-126 \mathrm{~m})$, although at several horizons, particularly within Cores $7(51-60 \mathrm{~m})$ and 12 $(87.96 \mathrm{~m})$, the $G$. ruber Assemblage is briefly and temporarily dominant. Isolated appearances of the Turborotalita "quinqueloba" (Sample 6-6, 55-57 cm) and Globigerinita glutinata (Sample 14-1, 55-57 cm) Assemblages were observed as well (50 and $105 \mathrm{~m}$, respectively). Globigerinoides conglobatus is rare in the upper 51 meters of this zone, but is essentially absent below Core 6; Globigerinella siphonifera and Globorotalia cultrata occur consistently in Cores 1 through $7(0-60 \mathrm{~m})$, but are present sporadically below only within this zone. Orbulina universa is present in most samples within this interval, but is essentially absent below.
Samples 16-4, 55-57 cm through 29-3, 50-52 cm $(126-240 \mathrm{~m})$ are assigned to the Globigerinoides ruber Zone. Both $G$. ruber and $G$. obliquus (which disappears near the top of this interval with "Globigerina" rubescens decoraperta) are present in most samples throughout this sequence, although $G$. quadrilobatus is sometimes briefly present, especially in Core 21 (164-170 m). Globorotalia limbata and $G$. cf. praemiocenica occur in a few samples in Cores 21 through 27 (164-223 m).

Below Core 29, planktonic foraminifera are rare. The small assemblages in Samples 29,CC through 30-3, 50-52 $\mathrm{cm}(242-248 \mathrm{~m})$ are dominated by Globigerinita glutinata; the remaining isolated planktonic faunas, present as low as Sample $33-4,48-50 \mathrm{~cm}(274 \mathrm{~m})$ generally contain only Turborotalita "quinqueloba."

Benthic foraminifera of the $U$. tenuistriata Assemblage persist as low as Sample 20-2, 48-50 cm (158 m), just below the Pliocene-Pleistocene boundary. $H$. topanoeliensis Assemblage species are present as low as Sample 34-2, 49-51 cm (280 m).

The expanded section and relatively high sedimentation rates observed at this site are due to a sizable influx of terrigenous detritus, presumably from the west. Most samples contain large quantities of mica and fine sand, but because all benthic species observed in Red Sea sediments are characteristic of relatively shallow depths, no direct evidence can be obtained at present on the amount of vertical displacement involved.

The earliest age determined at this site from nannofossil assemblages is late Early Pliocene (Reticulofenestra pseudoumbilica Zone) in Core 32; the assumed Late Miocene age for the evaporites here thus cannot be documented. It seems probable that much of Early Pliocene time at Site 228 is represented by an unconformity, but in the absence of adequate paleontologic control its existence cannot be conclusively demonstrated.

\section{Site 229}

Most of the samples recovered at Site 229 can be assigned to the Globigerinoides quadrilobatus Zone, particularly as the oldest samples observed are of Late Pleistocene (Coccolithus doronicoides Zone) age (Chapter 19 , this volume). Whether the zonation system applied at the other sites should be employed here is questionable, however, in view of the ecological basis of the zonation and the environmental differences presently existing between this and the northern sites.

The high species diversity, relative to other Red Sea assemblages, has been discussed earlier. Maximum diversity occurs, not at the top of the interval, however, but in Cores $4 \mathrm{~A}$ through $6 \mathrm{~A}-2,50-52 \mathrm{~cm}(56-76 \mathrm{~m})$, where a temporary influx of dextrally coiled Turborotalia pachyderma was observed. Other than the appearance of this form, however, there are few significant changes in faunal composition above Sample 7A,CC (92 m). Below this horizon, many of the species present here but not farther north occur more sporadically, although most persist intermittently throughout the recovered sequence. In a number of samples, particularly below Core $12 \mathrm{~A}(157 \mathrm{~m})$, faunas are reduced to four or five species, and several are dominated (e.g., Core 16, Sections $3,4,5,6$ ) by Turborotalita "quinqueloba." 
Benthic foraminifera are present and often common in most samples, and represent the $U$. tenuistriata Assemblage.

The extremely high sedimentation rates calculated for this site and the primarily biogenous nature of the sediment indicate the presence of considerable reworking from adjacent regions. This is reflected in the foraminiferal populations, particularly below Core 7A $(92 \mathrm{~m})$, by high percentages of poorly preserved (generally filled) tests, which sometimes constitute the entire foraminiferal fauna, benthic as well as planktonic. In general, the species compositions of poorly and well-preserved faunas appear to be similar, but they have not yet been analyzed in detail. As a result, the time differential represented by the two associations cannot as yet be determined.

\section{ACKNOWLEDGMENTS}

Appreciation is due to F. L. Parker (Scripps Institution of Oceanography); to O. L. Bandy, D. S. Gorsline, E. S. Vincent, and W. C. Meyer (University of Southern California); and to W. E. Frerichs (University of Wyoming) for helpful discussions and comments during the preparation of this report. J. Worral, of U. S. C., is responsible for the scanning electron micrographs.

This study was supported under Oceanographic Section, National Science Foundation NSF Grant GA-34145 and represents Contribution Number 329, Department of Geological Sciences, University of Southern California.

\section{REFERENCES}

Asano, K., Ingle, J. C., and Takayanagi, Y., 1968. Origin and development of Globigerina quinqueloba Natland in the North Pacific: Sci. Repts. Tohoku Univ., 2nd Ser. (Geol.), v. 39, p. 213-241.

Bandy, O. L., 1960. General correlation of foraminiferal structure with environment: Int. Geol. Congr. Repts., XXI Sess., Norden, pt. XXII, p. 7-19.

\section{2a. Origin and development of Globorotalia}

(Turborotalia) Pachyderma (Ehrenberg): Micropaleontology, v. 18 , p. $294-318$.

1972b. Variations in Globigerina bulloides d'Orbigny as indices of water masses: U. S. Antarctic J., v. 7, p. 194-195.

Bandy, O. L., Casey, R. E., and Wright, R. C., 1971. Late Neogene planktonic zonation, magnetic reversals, and radiometric dates, Antarctic to the tropics. In Reid, J. L. (Ed.), Antarctic Res. Ser., v. 15, Antarctic Oceanology I; p. $1-26$.

Banerji, R. K., Schafer, C. T., and Vine, R., 1971. Environmental relationships and distribution of planktonic foraminifera in the equatorial and northern Pacific waters: Atlantic Oceanogr. Lab., Bedford Inst., AOL Rept. 1971-7, p. 1-65.

Banner, F. T. and Blow, W. H., 1960. Some primary types of species belonging to the superfamily Globigerinaceae: Contrib. Cushman Found. Foram. Res., v. 11, pt. 1, p. $1-41$.

Barker, R. W., 1960. Taxonomic notes on the species figured by $\mathrm{H}$. B. Brady in his report on the foraminifera dredged by H. M. S. Challenger: Soc. Econ. Paleont. Mineral., Spec. Pub. 9, p. 1-238.

Bé, A. W. H., 1960. Ecology of Recent planktonic foraminifera: Part 2-Bathymetric and seasonal distributions in the Sargasso Sea off Bermuda: Micropaleontology, v. 6, p. 373-392.
Bé, A. W. H. and Hamlin, W. H., 1967. Ecology of Recent planktonic foraminifera; Part 3-Distribution in the North Atlantic during the summer of 1962: Micropaleontology, v. 13, p. 87-106.

Bé, A. W. H. and Tolderlund, D. S., 1971. Distribution and ecology of living planktonic foraminifera in surface waters of the Atlantic and Indian oceans. In Funnell, B. M. and Riedel, W. R. (Eds.), Micropaleontology of oceans: London (Cambridge Univ. Press), p. 105-149.

Beljaeva, N. V., 1964. Raspredelenie planktonnych foraminifer v. vodach i na dne Indiiskogo okeana: Akad. Nauk. SSSR, Trudy Inst. Okeanologii, v. 68, p. 12-83.

Berger, W. H. and Piper, D. J. W., 1972. Planktonic foraminifera: differential settling, dissolution, and redeposition: Limnol. Oceanogr., v. 17, p. 275-287.

Berggren, W. A., 1969. Micropaleontologic investigations of Red Sea cores-summation and synthesis of results. In Degens, E. T., and Ross, D. A. (Eds.), Hot brines and Recent heavy metal deposits in the Red Sea: New York (Springer-Verlag), p. 329-335.

Berggren, W. A. and Boersma, A., 1969. Late Pleistocene and Holocene planktonic foraminifera from the Red Sea. In Degens, E. T. and Ross, D. A. (Eds.), Hot brines and Recent heavy metal deposits in the Red Sea: New York (Springer-Verlag), p. 282-298.

Blow, W. H., 1969. Late Middle Eocene to Recent planktonic foraminiferal biostratigraphy: Int. Conf. Plankt. Microfossils, 1st, Proc., Brönimann, P. and Renz, H. H. (Eds.), Leiden (Brill), v. 1, p. 199-422.

Boltovskoy, E., 1969. Living planktonic foraminifera at the $90^{\circ} \mathrm{E}$ meridian from the equator to the antarctic: Micropaleontology, v. 15, p. 237-255.

Boltovskoy, E. and Lena, H., 1970. On the decomposition of the protoplasm and the sinking velocity of the planktonic foraminifers: Int. Rev. ges. Hydrobiol., v. 55, p. 797-804.

Bradshaw, J. S., 1959. Ecology of living planktonic foraminifera in the north and equatorial Pacific Ocean: Contrib. Cushman Found. Foram. Res., v. 10, pt. 2, 25-64.

Brönnimann, P. and Resig, J., 1971. A Neogene Globigerinacean biochronologic time-scale of the southwestern Pacific. In Winterer, E. L. et al., Initial Reports of the Deep Sea Drilling Project, Volume 7, Washington (U. S. Government Printing Office) p. 1235-1469.

Burek, P. J., 1969. Structural effects of sea-floor spreading in the Gulf of Aden and the Red Sea on the Arabian shield: In Degens, E. T. and Ross, D. A. (Eds.), Hot brines and Recent heavy metal deposits in the Red Sea: New York (Springer-Verlag), p. 59-70.

Chen, C., 1969. Pteropods in the hot brine sediments of the Red Sea: In Degens, E. T. and Ross, D. A. (Eds.), Hot brines and Recent heavy metal deposits in the Red Sea: New York (Springer-Verlag), p. 313-316.

Ciaranfi, N. and Cita, M. B., 1973. Paleontological evidence of changes in the Pliocene climates. In Ryan, W. B. F., Hsü, K. J., et al., Initial Reports of the Deep Sea Drilling Project, Volume 13: Washington (U. S. Government Printing Office), p. 1387-1399.

Cita, M. B., Chierici, M. A., Ciampo, G., Moncharmont Zei, M., d'Onofrio, S., Ryan, W. B. F., and Scorziello, R., 1973. The Quaternary record in the Tyrrhenian and Jonian Basins of the Mediterranean Sea: In Ryan, W. B. F., Hsü, K. J., et al., Initial Reports of the Deep Sea Drilling Project, Volume 13: Washington (U. S. Government Printing Office), p. 1263-1339. 
Craig, H., 1969. Geochemistry and origin of the Red Sea brines: In Degens, E. T. and Ross, D. A. (Eds.), Hot brines and Recent heavy metal deposits in the Red Sea: New York (Springer-Verlag), p. 208-242.

Cushman, J. A., 1910-1917. A monograph of the foraminifera of the north Pacific Ocean: U. S. Nat. Museum Bull. 71, pt. 1-6, p. 1-608.

, 1932-1942. The foraminifera of the tropical Pacific collections of the "Albatross," 1899-1900: U. S. Nat. Museum Bull. 161.pt. 1-3, p. 1-234.

Cushman, J. A., Todd, R., and Post, R. J., 1954. Recent foraminifera of the Marshall Islands: U. S. Geol. Surv. Prof. Paper 260-H, p. 319-384.

Dietrich, G., Düing, W., Grasshoff, K., and Koske, P. H., 1966. Physikalische und chemische Daten nach Beobachtungen des Forschungsschiffes "Meteor" im Indischen Ozean 1964/65: "Meteor" Forsch.-Ergeb., Reihe A, no. 2.

Frerichs, W. E., 1970. Distribution and ecology of benthonic foraminifera in the sediments of the Andaman Sea: Contrib. Cushman Found. Foram. Res., v. 21, pt. 4, p. 123-147.

Girdler, R. W., 1969. The Red Sea-a geophysical background. In Degens, E. T. and Ross, D. A. (Eds.), Hot brines and Recent heavy metal deposits in the Red Sea: New York (Springer-Verlag), p. 38-58.

Grasshoff, K., 1969. Zur chemie des Roten Meeres und des Inneren Golfs von Aden: "Meteor" Forsch.-Ergeb., Reihe A, no. 6, p. 1-76.

Herman, Y, 1965. Etudes des sédiments quaternaires de la Mer Rouge: Ann. Inst. Océanogr. Paris (Masson and Co.), v. 42 , p. $339-415$. 1971. Vertical and horizontal distribution of pteropods in Quaternary sequences. In Funnell, B. M., and Riedel, W. R. (Eds.), Micropaleontology of Oceans: London (Cambridge Univ. Press) p. 463-486.

Herman, Y. and Rosenberg, P. E., 1969. Mineralogy and micropaleontology of a goethite-bearing Red Sea core. In Degens, E. T. and Ross, D. A. (Eds.), Hot brines and Recent heavy metal deposits in the Red Sea: New York (Springer-Verlag), p. 448-459.

Heybroek, F., 1965. The Red Sea Miocene evaporite basin. In Salt Basins around Africa: London (Inst. of Petroleum), p. 17-40.

Hsü, K. J., Cita, M. B., and Ryan, W.B.F., 1973. The origin of the Mediterranean evaporites. In Ryan, W.B.F., Hsü, K. J., et al., Initial Reports of the Deep Sea Drilling Project, Volume 13: Washington (U. S. Government Printing Office), p. 1203-1231.

Jenkins, D. G. and Orr, W. N., 1972. Planktonic foraminiferal biostratigraphy of the eastern equatorial PacificDSDP Leg 9. In Hays, J.D. et al., Initial Reports of the Deep Sea Drilling Project, Volume 9: Washington (U. S. Government Printing Office),p. 1059-1193.

Jones, J. I., 1968. The relationship of planktonic foraminiferal populations to water masses in the western Caribbean and lower Gulf of Mexico: Marine Sci. Bull., v. 18 , p. $946-982$.

Kheradpir, A., 1970. Foraminiferal trends in the Quaternary of Tanner Basin, California: Micropaleontology, v. 16, p. $102-116$

Knott, S. T., Bunce, E. T., and Chase, R. L., 1966. Red Sea seismic reflection studies. In The world rift system: Geol. Surv. Canada Paper 66-14, p. 33-61.

Lamb, J. L. and Beard, J. H., 1972. Late Neogene planktonic foraminifers in the Caribbean, Gulf of
Mexico, and Italian stratotypes: Univ. Kansas Paleont. Contrib., art. 57 (Protozoa 8), p. 1-67.

Laughton, A. S., 1970. A new bathymetric chart of the Red Sea: Phil. Trans. Roy. Soc. London, Series A, v. 267, p. 21-22.

LeRoy, L. W., 1941. Small foraminifera from the Late Tertiary of the Netherlands East Indies: Colorado School Mines Quart., v. 36, p. 5-132.

1944. Miocene foraminifera from Sumatra and Java, Netherlands East Indies: Colorado School Mines Quart., v. 39, p. 7-113.

1964. Smaller foraminifera from the Late Tertiary of southern Okinawa: U. S. Geol. Surv. Prof. Paper 454-F, p. F1-F58.

Lipps, J. H. and Valentine, J. W., 1970. The role of foraminifera in the trophic structure of marine communities: Lethaia, v. 3, p. 279-286.

Lowell, J. D. and Genik, G. J., 1972. Sea-floor spreading and structural evolution of southern Red Sea: Am. Assoc. Petrol. Geol. Bull., v. 56, p. 247-259.

Meyer, W. C., 1973. Late Pleistocene and Holocene paleoceanography of the Red Sea: Unpublished M.S. thesis, University of Southern California.

Morcos, S. A., 1970. Physical and chemical oceanography of the Red Sea: Oceanogr. Mar. Biol. Ann. Rev., v. 8, p. 73-202.

Nasu, K. and Shimano, T., 1966. The physical results of oceanographic survey in the southeast Indian Ocean: J. Tokyo Univ. Fisheries, v. 8, p. 133-157 (Japanese with English summary; cited in Ujiié, 1968.).

Natland, M. L., 1938. New species of foraminifera from off the west coast of North America and from the later Tertiary of the Los Angeles basin: Scripps Inst. Oceanogr., Tech. Ser. Bull., v. 4, p. 137-164.

Nesteroff, W. D., 1973. Mineralogy, petrography, distribution, and origin of the Messinian Mediterranean evaporites. In Ryan, W.B.F., Hsü, K. J., et al., Initial Reports of the Deep Sea Drilling Project, Volume 13: Washington (U.S. Government Printing Office), p. 673-694.

Olausson, E., 1960. Description of sediment cores from the Mediterranean and the Red Sea: Swedish Deep-Sea Exped. Repts., v. 8, p. 287-334.

Olsson, R. K., 1973. Pleistocene history of Globigerina pachyderma (Ehrenberg) in Site 36, Deep-Sea Drilling Project, northeastern Pacific: Am. Assoc. Petrol. Geol. Bull., v. 57, p. 798 (abstract).

Parker, F. L., 1958. Eastern Mediterranean foraminifera: Swedish Deep-Sea Exped. Repts., v. 8, p. 219-283.

1962. Planktonic foraminiferal species in Pacific sediments: Micropaleontology, v. 8, p. 219-254.

1967. Late Tertiary biostratigraphy (planktonic foraminifera) of tropical Indo-Pacific deep-sea cores: Am. Paleont. Bull., v. 52, p. 115-208.

Patzert, W. C., 1972. Seasonal variations in structure and circulation in the Red Sea: Hawaii Inst. Geophys. Rept. HIG-72-13, p. 1-58.

Privett, D. W., 1959. Monthly charts of evaporation from the North Indian Ocean, including Red Sea and Persian Gulf: Quart. J. Roy. Meteor. Soc., v. 85, p. 424-428.

Ross, D. A., Hays, E. E., and Allstrom, F. C., 1969. Bathymetry and continuous seismic profiles of the hot brine region of the Red Sea: In Degens, E. T. and Ross, D. A. (Eds.), Hot brines and Recent heavy metal deposits in the Red Sea: New York (Springer-Verlag), p. 82-97. 
Ross, D. A., Whitmarsh, R. B., Ali, S. A., Boudreaux, J. E., Coleman, R., Fleisher, R. L., Girdler, R., Manheim, F., Matter, A., Nigrini, C., Stoffers, P., and Supko, P. R., 1973. Red Sea Drillings: Science, v. 179 , p. 377-380.

Ryther, J. H., 1969. Photosynthesis and fish production in the sea: Science, v. 166, p. 72-76.

Said, R., 1949. Foraminifera of the northern Red Sea: Cushman Lab. Foram. Res., Spec. Pub. 26, p. 1-44. , 1950a. Additional foraminifera from the northern Red Sea: Contrib. Cushman Found. Foram. Res., v. 1, pts. 1 and 2, p. 4-9. 1950b. The distribution of foraminifera in the northern Red Sea: Contrib. Cushman Found. Foram. Res., v. 1, pts. 1 and 2, p. 9-29.

Said, R. and Basiouni, M. A., 1958. Calabrian microfossils from Kom El Shellul, Giza: Egypt. J. Geol., v. 2, p. 147-178.

Said, R. and Kamel, T., 1956. Recent littoral foraminifera from the Egyptian Mediterranean coast between Rosetta and Saloum: Inst. Egypt Bull., v. 37, p. 341-372.

Said, R. and Kamel, T., 1957. The distribution of foraminifera in the Egyptian Mediterranean coast: Egypt. J. Geol., v. 1, p. 143-155.

Schmalz, R. F., 1969. Deep-water evaporite deposition: a genetic model: Am. Assoc. Petrol. Geol. Bull., v. 53, p. 798-823.

Selli, R., 1967. The Pliocene-Pleistocene boundary in Italian marine sections and its relationship to continental stratigraphies. In Sears, M. (Ed.) Progress in oceanography: New York (Pergammon Press) v. 4, p. 67-86.

Siedler, G., 1968. Schichtungs-und Bewegungsverhältnisse am Südausgang des Roten Meeres: "Meteor" Forsch.Ergeb., Reihe A, no. 4.
1969. General circulation of water masses in the Red Sea. In Degen, E. T. and Ross, D. A. (Eds.), Hot brines and Recent heavy metal deposits in the Red Sea: New York (Springer-Verlag), p. 131-137.

Todd, R., 1958. Foraminifera from western Mediterranean deep-sea cores: Swedish Deep-Sea Exped. Repts., v. 8, p. 169-215

1965. The foraminifera of the tropical Pacific collections of the "Albatross," 1899-1900: U.S. Nat. Museum Bull., v. 161, Pt. 4.

Tolderlund, D. S. and Bé, A.W.H., 1971. Seasonal distribution of planktonic foraminifera in the western North Atlantic: Micropaleontology, v. 17, p. 297-329.

Tramontini, C. and Davies, D., 1969. A seismic refraction survey in the Red Sea: Geophys. J., Roy. Astr. Soc., v. 17 , p. $225-241$.

Ujiié, H., 1968. Distribution of living planktonic foraminifera in the southeast Indian Ocean: Nat. Sci. Museum Bull., v. 11, p. 97-125.

Vine, F. J., 1966. Spreading of the ocean floor-new evidence: Science, v. 154 , p. 1405-1415.

Zobel, B., 1971. Foraminifera from plankton tows, Arabian Sea: areal distribution as influenced by ocean water masses: Plankt. Conf. 2nd Rome, 1970, Proc., Farinacci, A. (Ed.), Rome (Edizioni Tecnoscienza), v. 2, p. 1323-1335.

1973. Biostratigraphische Untersuchungen an Sedimenten des indischpakistanischen Kontinentalrandes (Arabisches Meer): "Meteor" Forsch.-Ergeb., Reihe C, no. 12 , p. $9-73$. 



\section{PLATE 1}

" $D$ " indicates maximum diameter or length of specimen measured on illustrated orientation. Size bar represents $0.10 \mathrm{~mm}$. Illustrations are of different specimens unless otherwise indicated. All illustrated specimens have been deposited in the collections of the U. S. National Museum, Washington, D. C.

Figures 1-4 Globorotalia (G.) cf. praemiocenica Lamb and Beard; all from Sample 225-11-2, $52-54 \mathrm{~cm}$.

1. Dorsal view. $\mathrm{D}=0.63 \mathrm{~mm}$.

2. Ventral view; same specimen as Figure 1.

3. Side (apertural) view; same specimen as Figure 1.

4. Side (apertural) view of less-inflated specimen. $\mathrm{D}=$ $0.58 \mathrm{~mm}$.

Figures 5-7 Turborotalia (T.) sp. 1; all from Sample 225-17-1, $120-122 \mathrm{~cm}$.

5. Ventral view. $\mathrm{D}=0.33 \mathrm{~mm}$.

6. Dorsal view. $\mathrm{D}=0.34 \mathrm{~mm}$.

7. Side (apertural) view. $\mathrm{D}=0.34 \mathrm{~mm}$. 


\section{PLATE 1}
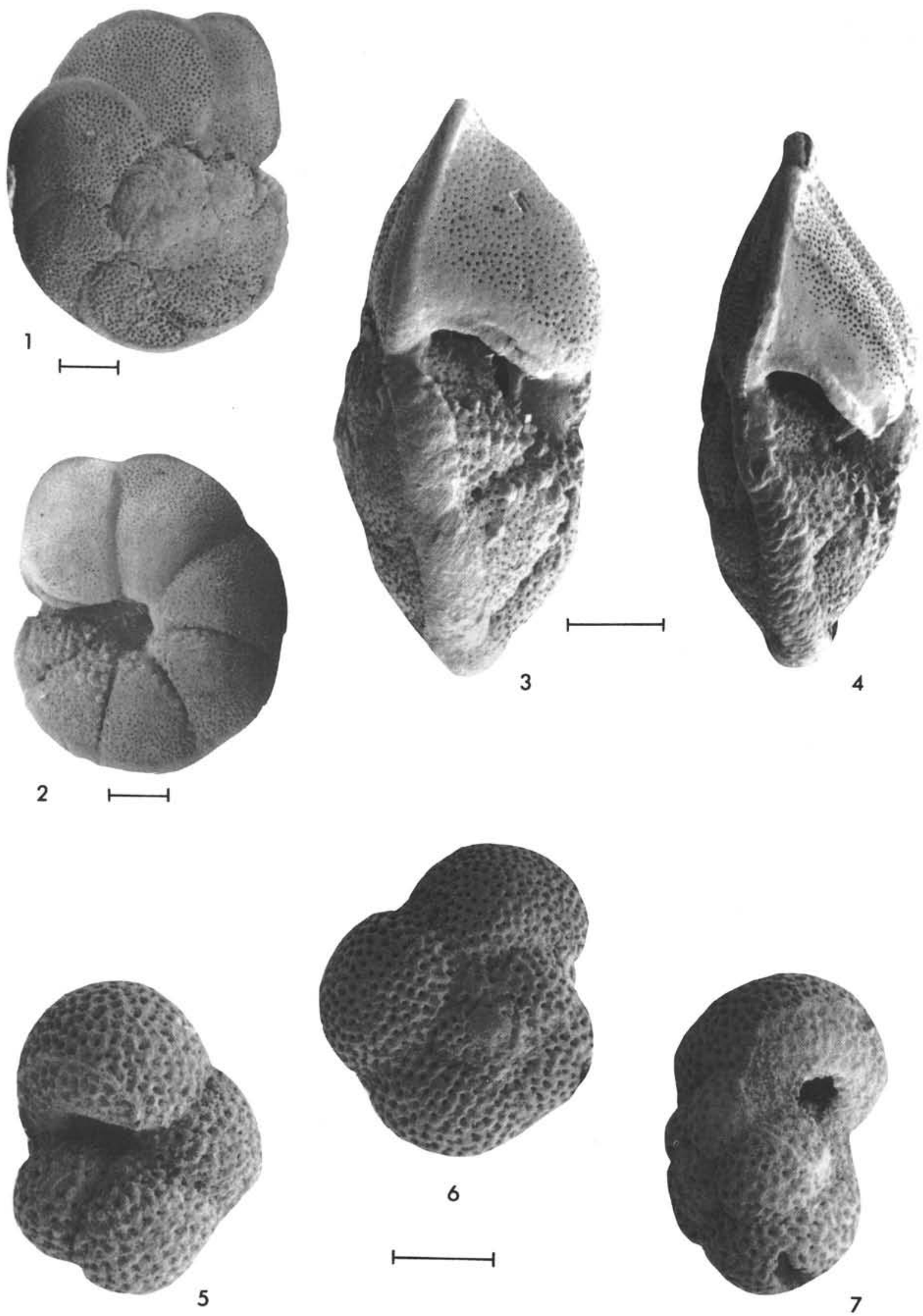


\section{PLATE 2}

Figures 1-3 Five-chambered form of Turborotalia (T.) sp. 1; all from Sample 225-17-1, 120-122 cm.

1. Ventral view. $\mathrm{D}=0.35 \mathrm{~mm}$.

2. Dorsal view. $\mathrm{D}=0.37 \mathrm{~mm}$.

3. Side (apertural) view. $\mathrm{D}=0.42 \mathrm{~mm}$.

Figures 4-6 Turborotalita "quinqueloba"; all from Sample $225-4-5,51-53 \mathrm{~cm}$.

4. Ventral view. $D=0.11 \mathrm{~mm}$. Spines and circular pores are concentrated in, but not restricted to, peripheral region.

5. Dorsal view. $\mathrm{D}=0.11 \mathrm{~mm}$. Note elongate pores (?) situated along dorsal sutures.

6. Side (apertural) view. $\mathrm{D}=0.12 \mathrm{~mm}$.

Figures 7, $8 \quad$ Streptochilus globigerum (Schwager); all from Sample 225-19-3, $49-51 \mathrm{~cm}$.

7. Side view. $\mathrm{D}=0.26 \mathrm{~mm}$.

8. Apertural view. $\mathrm{D}=0.26 \mathrm{~mm}$.

Figures 9, 10 Unidentified microfossils; all from Sample 225-15-2, $49-51 \mathrm{~cm}$.

9. Side view. $\mathrm{D}=0.12 \mathrm{~mm}$.

10. Top view. $\mathrm{D}=0.11 \mathrm{~mm}$. 


\section{PLATE 2}
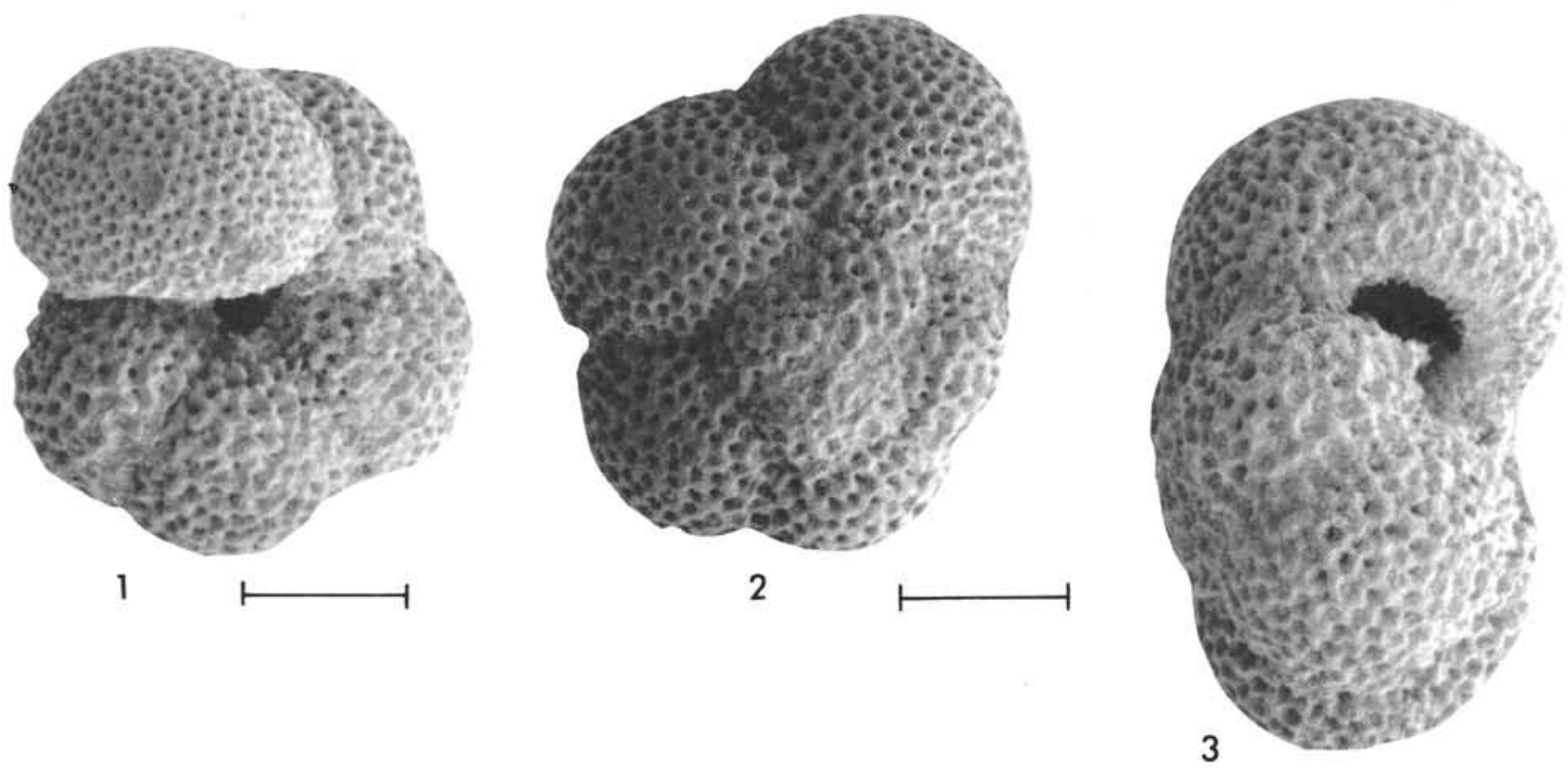

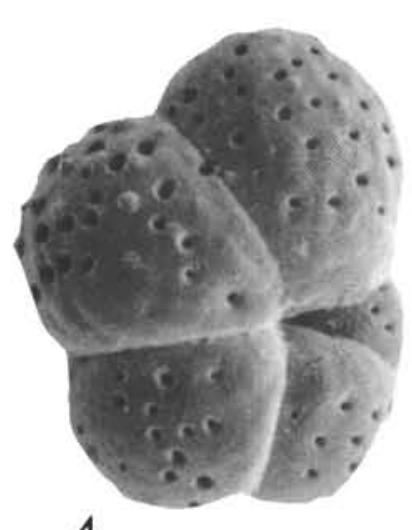

4
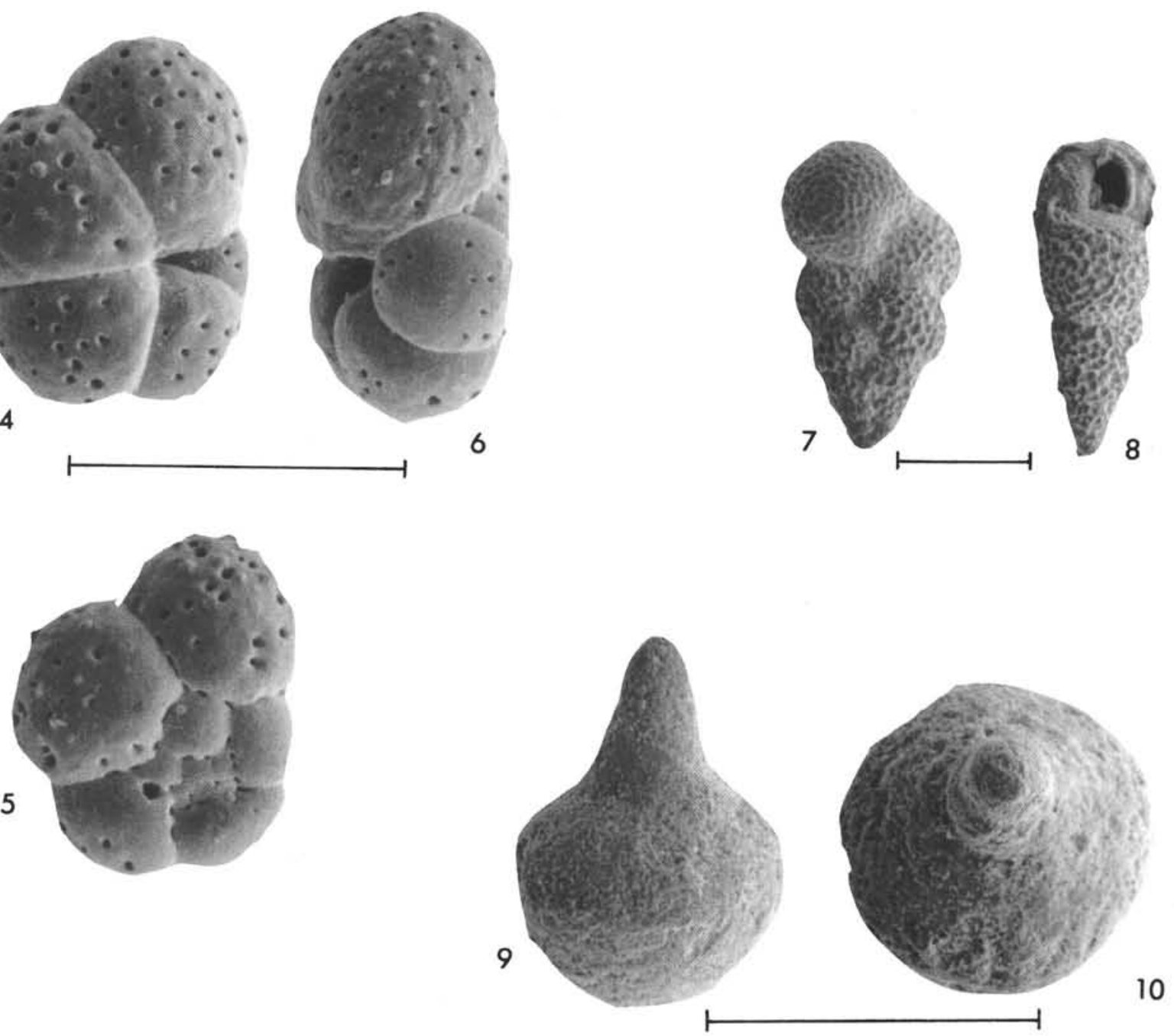